NBER WORKING PAPER SERIES

\title{
THE INFLUENCE OF UNIVERSITY RESEARCH ON INDUSTRIAL INNOVATION
}

\author{
Jinyoung Kim \\ Sangjoon John Lee \\ Gerald Marschke \\ Working Paper 11447 \\ http://www.nber.org/papers/w11447
NATIONAL BUREAU OF ECONOMIC RESEARCH
1050 Massachusetts Avenue
Cambridge, MA 02138
June 2005

We would like to thank Adam Jaffe and participants of the NBER conference "Academic Science and Entrepreneurship: Dual Engines of Growth?” April 2005, Santa Fe, New Mexico. All errors are exclusively the responsibility of the authors. Lee is grateful to the National Bureau of Economic Research for the NBERSloan Science and Engineering Workforce Project Fellowship. Comments welcome at Jinyoung Kim, Department of Economics, SUNY Buffalo, 441 Fronczak Hall, Buffalo, NY 14620, jinkim@buffalo.edu; and Gerald Marschke, Department of Economics, SUNY Albany, BA-110, Albany, NY 12222, marschke@albany.edu. We thank Courtney Hayden and Lei Zhang for their excellent research assistance. The views expressed herein are those of the author(s) and do not necessarily reflect the views of the National Bureau of Economic Research.

C2005 by Jinyoung Kim, Sangjoon John Lee, and Gerald Marschke. All rights reserved. Short sections of text, not to exceed two paragraphs, may be quoted without explicit permission provided that full credit, including (C) notice, is given to the source. 
The Influence of University Research on Industrial Innovation

Jinyoung Kim, Sangjoon John Lee, and Gerald Marshke

NBER Working Paper No. 11447

June 2005

JEL No. J62, O31, O33

\section{ABSTRACT}

We use U.S. patent records to examine the role of research personnel as a pathway for the diffusion of ideas from university to industry. Appearing on a patent assigned to a university is evidence that an inventor has been exposed to university research, either directly as a university researcher or through some form of collaboration with university researchers. Having an advanced degree is another indicator of an inventor's exposure to university research. We find a steady increase in industry's use of inventors with university research experience over the period 1985-97, economy wide and in the pharmaceutical and semiconductor industries in particular. We interpret this as evidence of growth in the influence of university research on industrial innovation. Moreover, during this period we find that firms with large research operations in both industries, and young and highly capitalized firms in the pharmaceutical industry, are disproportionately active in the diffusion of ideas from the university sector. Finally, we find that the patents of firms that employ inventors with university research experience are more likely to cite university patents as prior art, suggesting that this experience better enables firms to tap academic research.

Jinyoung Kim

Department of Economics

SUNY Buffalo

441 Fronczak Hall

Buffalo, NY 14260

jinkim@buffalo.edu
Gerald Marschke

Department of Economics

SUNY Albany

BA-110

Albany, NY 12222

marschke@albany.edu 


\section{Introduction}

This paper examines the influence of university research on innovation in industry. The results of university research disseminate along a number of pathways: through scholarly publications and the material published in universities' patent applications, at conferences where scholarly work is presented and where industry and academic research personnel commingle, and via informal social networks. ${ }^{1}$ But firms also learn about university research after employing or collaborating with researchers who work or have worked in university laboratories. In fact, social scientists who study innovation suspect that certain kinds of important knowledge become available to a firm only with sustained, close interaction with researchers who possess this knowledge as through an employment or collaborative research arrangement.

We use U.S. patent data to study the role of research personnel as a pathway for the diffusion of ideas from university to industry. The inventors behind the patented invention are listed on each patent, as are the firms, government organizations, and universities to which the patents are assigned. Using a procedure similar to one proposed by Trajtenberg (2004), we match names on patents to construct a panel data set of inventors that contains the patents in each year of the inventors' careers. We are thus able to identify for each inventor when and how often he or she is innovating for university and industry assignees. For each patent assigned to industry we can tell whether its inventors had previously appeared as an inventor on a patent assigned to a university. Appearing on a patent assigned to a university is evidence that the inventor had exposure to university research, either directly as a university researcher or through

\footnotetext{
${ }^{1}$ See Cohen, Nelson and Walsh (2002) on the various means by which innovating firms access know-how developed externally. See Agrawal, Cockburn, and McHale (2003) for evidence of the importance of social networks in promoting diffusion.
} 
some form of collaboration with university researchers. We also use data from the Dissertation Abstracts to establish whether the inventor has an advanced degree (doctorate or master’s), another measure of exposure to university research. In this paper, we investigate how the influence of university research on industry innovation has evolved over the last two decades, through inventors' university inventing and research experience. In addition, we investigate how the trend of university influence can be attributed to various factors like the demand and the supply of university-affiliated scientists by decomposing the change in university influence into components representing various factors.

We also use patent citations to infer the extent of industry access to universityproduced knowledge and how that access has changed. Patent applicants are legally obligated to disclose any knowledge they have of previous relevant inventions. The patent examiner may add to the application relevant citations omitted by the applicant. Thus, through the patent citations each patent documents the "prior art" upon which the new innovation builds, and because we know each cited patent's assignee type, we know whether the prior art originated in university laboratories. ${ }^{2}$ We also investigate if the presence of university-affiliated inventors instigates firms to cite university patents and access university research.

Another objective of our paper is to identify factors that influence an innovating firm's interaction with university R\&D. A focus of this analysis is the pharmaceutical and semiconductor industries, two industries that are especially prolific generators of innovations and patents. After combining the inventor panel data with firm information

\footnotetext{
${ }^{2}$ Other studies have examined citations to university patents (e.g., Jaffe and Trajtenberg, 2002), but to our knowledge, none have looked at how the phenomenon has been evolving.
} 
in these industries, we relate various firm-level characteristics with our measures of exposure to university research to sort out the factors that influence an innovating firm's interaction with university research. We also repeat the analyses conducted on the comprehensive industry-wide data separately for the pharmaceutical and semiconductor industries to find how the influence of university research has evolved in these two industries.

Our main findings are the following. Over the period 1985-1997, we find industry increased its employment of inventors with experience on university research projects and with advanced university degrees. For the decade of the 1990s we also find (1) the pharmaceutical industry made greater use of inventors with university backgrounds than the semiconductor industry, (2) the percentage of patents assigned to firms that involved inventors with university backgrounds increased substantially in both industries, (3) that firms with large research enterprises in both industries and young and highly capitalized firms in the pharmaceutical industry were disproportionately active in the diffusion of ideas from the university sector, and (4) the patents of firms that employ inventors with university patenting experience are more likely to cite university patents as prior art.

The paper is organized as follows. The next section summarizes the literature on the various mechanisms for university technology transfer to industry, technology spillovers, scientist collaboration and mobility, and the use of patent citations to trace technological diffusion. Section III describes our data, focusing on the construction of the inventor panel. Section IV describes levels and trends in university involvement in all industries and by industry, and reports the decomposition results. This section also 
describes our empirical estimation of the determinants of firm use of universityexperienced inventors and inventors with advanced degrees, and of citations to university patents. Section V offers concluding remarks.

\section{Literature Review}

Two decades of empirical work suggests important and pervasive effects of university research on industry R\&D and innovation (e.g., Jaffe, 1989; Adams, 1990; Mansfield, 1991, 1998; Nelson and Rosenberg, 1993; Cohen, Nelson, and Walsh, 2002). ${ }^{3}$ Mansfield (1991) roughly estimates the annual social rate of return to university research over the years 1975 through 1978 to be 28 percent. While the diffusion of technology from the academic to the industrial sector is thought to be important, little is known about the transmittal mechanisms. Scholars writing in both the economics and sociology of innovation literatures argue that new technologies are frequently difficult to transmit to the uninitiated via spoken or written communication (see Polyani, 1958, for an early discussion of the 'tacitness' of knowledge). Often the most efficient means of transmission across organizational boundaries for tacit knowledge is via person-to-person contact involving a transfer or exchange of personnel. Recent findings that technological diffusion appears to be geographically limited (e.g., Jaffe, 1989; Jaffe, Trajtenberg, and Henderson, 1993; Zucker, Darby, and Brewer, 1998; and Mowery and Ziedonis, 2001) is often interpreted as evidence of the tacitness of knowledge.

More direct evidence exists that person-to-person interaction is important for the diffusion of technology. Cohen, Nelson, and Walsh (2002) surveyed R\&D managers on the means by which they gather and assimilate new technologies. They find that firms

\footnotetext{
${ }^{3}$ See Cohen, Florida, Randazzese, and Walsh (1998) for a survey of this evidence.
} 
access externally-located technology partly through the hiring of and collaboration with researchers from the outside. Moreover, they find that hiring/collaboration with outside scientists is complementary to other means of accessing externally produced knowledge, such as through informal communications with outsiders and more formal (such as consulting) relationships with outsiders. Almeida and Kogut (1999) find that scientific references that firms cite in their patent applications reflect the employment histories of their inventors, suggesting that ideas in the semiconductor industry are spread by the movement of key engineers among firms, especially within a geographical area. ${ }^{4}$ Zucker, Darby, and Armstrong (2001) find evidence of a pay-off to firms that seek interactions with outside researchers. They find a positive impact on patent productivity for biotech firms that collaborate with university researchers on research and scholarly publications.

We therefore anticipate that the evidence, while presently incomplete, will eventually show that the migration of university-experienced scientific personnel to industry is an important means of technology transfer and that it complements other mechanisms. Assuming this to be the case, we use measures of the industrial employment of university-experienced researchers to track the extent to which industry is accessing university technologies.

We also use patent citations to track the diffusion of university innovations. Some scholars have used citations to university and industrial patents to compare the relative importance of innovations arising from these sectors and to examine how changes in patent law have influenced the importance of university patents (Henderson, Jaffe, and Trajtenberg, 1998; Sampat, Mowery, and Ziedonis, 2003). Others have looked

\footnotetext{
${ }^{4}$ See also the (indirect) evidence of a link between scientific mobility and technological diffusion in Kim and Marschke (2005) and Moen (2005).
} 
at the determinants of a university patent's likelihood of being cited (Jaffe and Trajtenberg, 2002) and the trend in citations of industry patents to university research publications (Narin et al., 1997). To our knowledge, ours is the first study that examines the extent to which industrial patents cite university patents.

\section{Data Description}

Our data are derived from six sources: (1) Patent Bibliographic data (Patents BIB) released by the U.S. Patent and Trademark Office (USPTO) that contain bibliographic information for U.S. utility patents issued from 1975 to 2002; (2) the ProQuest Digital Dissertation Abstracts database which contains information on the date, field, and type of degree for those who earned degrees in all natural science and engineering fields between 1945-2003; (3) the Compact D/SEC database since 1989 which contains firm information taken primarily from $10-\mathrm{K}$ reports filed with the Securities and Exchange Commission; (4) the Standard \& Poor's Annual Guide to Stocks-Directory of Obsolete Securities which include a history of firm name changes; (5) the Thomas Register, Mergent, and Corptech data which report a firm's founding year, and finally (6) the NBER PatentCitations data collected by Hall, Jaffe and Trajtenberg (2001) which contain all citations made by patents granted in 1975-1999. To create our database from these sources, we first match inventor names in the Patents BIB and Dissertation Abstracts databases. We then match firms in the Compact D/SEC database to assignees in the Patent BIB database with founding information added. Finally, we combine the two databases from the first two steps and add information from the citation data. 


\section{Inventor name matching}

Since the 1960's researchers have extensively used the information contained in patent data to investigate various issues such as technology spillovers and $R \& D$ productivity at the industry or firm level. The information on inventors contained in patent data, however, has not been fully utilized possibly because of the difficulty in identifying whether two names in the inventor name field from two patents belong to the same inventor. Using inventor's name (last, first, and middle), address, city, state, zip (often missing), and country at the time of grant of the patent, we attempt in this paper to match inventor names and produce each inventor's life-cycle productivity in patenting.

There are various potential problems in name matching in the patent data. First, full middle names are reported in some cases while only their initials are spelled out or they are missing in other cases. Second, there is a risk of two inventors with the same common names being mistakenly matched. Third, there can be a problem of name misspelling, especially for non English names. As an attempt to circumvent these potential problems, we rely on other information available from the patent data such as inventors' addresses, citation records, and postal zip codes. Our methodology for inventor name matching is similar to that in Trajtenberg (2004), which is the only other attempt for inventor name matching to our knowledge.

To start, we treat each entry that appears in the inventor name field of every patent in the Patents BIB data as a unique inventor. Given, let's say, N number of names in this name pool, we pair each name with all other names, which generates $\mathrm{N}(\mathrm{N}-1) / 2$ number of unique pairs. In fact our data have 5.1 million names in total (2.05 inventors per patent) and thus 13 trillion unique pairs. For each pair, we consider the two names as 
belonging to the same inventor if the SOUNDEX codes of their last names and their full first names are the same, and at least one of the following three conditions is met: (1) the full addresses for the pair of names are the same; (2) one name from the pair is an inventor of a patent that is cited by another patent whose inventors include the other name from the pair; or (3) the two names from the pair share the same co-inventor. These three criteria in our name matching method are similar to the "Strong" criteria of Trajtenberg (2004).

The SOUNDEX is a coded index for last names (surnames) based on the way a surname sounds rather than the way it is spelled. Surnames that sound the same, but are spelled differently, like SMITH and SMYTH, have the same SOUNDEX code. We use the SOUNDEX coding method to expand the list of similar last names to overcome the potential for misspellings and inconsistent foreign name translations to English; misspellings are common in the USPTO data as are names of non-Western European origin (see Appendix A for the detailed SOUNDEX coding method).

We also consider a pair of names as a match if two have the same full last and first names, and at least one of the following two conditions is met: (1) the two have the same zip code; or (2) they have the same full middle name. These two criteria correspond to the "Medium" criteria of Trajtenberg (2004).

Given all pairs of names that are considered as matches by the preceding procedures, we impose an additional matching criterion that a pair of names is not treated as a match if their middle name initials are different. We then impose transitivity in the following sense: If name $\mathrm{A}$ is matched to name $\mathrm{B}$ and name $\mathrm{B}$ is matched to name $\mathrm{C}$, name $\mathrm{A}$ is then matched to name $\mathrm{C}$. We iterate this process until all possible transitivity 
matches are completed. At this point we assign the same inventor ID number for all the names matched. ${ }^{5}$

Trajtenberg (2004) assigns scores for each matching criteria and considers a pair matched only if its total score from all matching criteria exceeds a threshold. We do not use this score method in our data construction because different scores given to each criterion and the threshold score can be quite arbitrary. Our methods also differ in that we do not match the pair of names with the same assignee because name matching based on this criterion can produce data with a bias in mobility among inventors. Instead we apply the criterion that a pair of names is not treated as a match if their middle name initials differ. From our experience with the patent data, imposing this criterion is necessary because the SOUNDEX coding system sometimes so loosely specifies names that apparently different last names are considered a match.

In the end, because of these differences the number of distinct inventors identified with our procedure is a little higher than the number of distinct inventors produced by Trajtenberg's method. We identified 2.3 million unique inventors (45\%) out of 5.1 million names in the entire patent data while Trajtenberg (2004) found 1.6 million distinctive inventors (37\%) out of 4.3 million names. Note that our patent database is larger because it includes additional years, 2000-2002.

After name matching in the patent data, we match the Dissertation Abstract data to the inventors in the patent data. Each inventor identified through the preceding

\footnotetext{
${ }^{5}$ Imposing transitivity after our name matching procedure, however, poses a possibility of name mismatch. Suppose, for example, Adam E. Smith and Adam Smith are matched based on our criteria in one pair, and the same Adam Smith and Adam J. Smith are matched in another pair. According to our transitivity procedure, Adam E. Smith and Adam J. Smith are identified as a match although their middle name initials are different. We thank Adam Jaffe for raising this issue. See Appendix B for the magnitude and the correction of this problem in our data.
} 
procedure may have a list of names matched to him or her (for example, John Maynard Keynes, John M. Keynes, John Keynes) due to names linked to each other by satisfying the criteria described above. Since the Dissertation Abstract data contain for each individual a full name in a string instead of separate last, first and middle name fields, we convert all the names under each inventor ID number in the patent data to strings to search for them within the Dissertation Abstract data. ${ }^{6}$ On rare occasions when multiple names from the Dissertation Abstract data are matched to one ID number in the patent data, we randomly pick one name. Out of 2.3 million unique inventors in our patent data, 3 percent $(64,507)$ are identified as holders of advanced degrees.

\section{Firm-assignee matching}

We choose all firms whose primary SIC code is 2834 (pharmaceutical preparation) or 3674 (semiconductor and related devices) in the Compact D/SEC data. ${ }^{7}$ We select these two industries for our study because the firms in these industries are active in patenting and produce homogenous products relative to other industries. By focusing on two relatively homogenous industries, we avoid problems due to the incomparability in utility and marketability of innovations, and in patent propensities across industries. Note that we select only the years 1989 through 1997 for our study, because the Compact D/SEC data before 1989 are unavailable to us and we found that

\footnotetext{
${ }^{6}$ In addition, we impose conditions regarding the timeframe of the inventor's patenting history, wherein the inventor's last patent is no later than forty years following the dissertation date, and the first patent is no more than twenty years before the dissertation date.

${ }^{7}$ Because the Compact D/SEC database contains only publicly traded firms that have at least $\$ 5$ million in assets, our sample contains firms that are on average larger and more successful than the firms in the general population in these industries. Also, most biotech firms are not included in our pharmaceutical industry sample because we selected only those firms under one SIC code of pharmaceutical preparation.
} 
starting with application year 1998 the patent time series tailed off due to the review lag at the USPTO.

Because parent firms patent sometimes under their own names and at other times under the names of their subsidiaries, merging the Patents BIB data with firm-level data in the Compact D/SEC data is not straightforward. Mergers and acquisitions at both the parent firm and subsidiary levels, common in these two industries during the 1990s, and name changes further complicate linking the patent to firm-level data. (The USPTO does not maintain a unique identifier for each patenting assignee at the parent firm level nor does it track assignee name changes.) Thus, to use the firm-level information available in the Compact D/SEC data, the names of parent firms and their subsidiaries and the ownership of firms must be tracked over the entire period of the study, which is accomplished based on the subsidiary information in the Compact D/SEC data.

Since the Compact D/SEC data do not report old names of the firms that change their names (in many cases, after mergers), we use the S\&P data to track the history of name changes of each assignee and link firm level information in the Compact D/SEC data before and after a name change. Finally, we merge information on firms' founding years to the firm database.

\section{Combining databases from the preceding steps}

As the final step, we link the patent inventor database from the first step to the firm database from the second step to produce a data set on inventors and patents that includes firm-level data (e.g., R\&D expenditures, sales, and employment level) on the patents' assignees. Because patents are typically assigned to the firm (the assignee) that 
employs the inventors, we identify the inventors' employers in the Patents BIB data by patent assignees. We then add information on all citations from the NBER PatentCitations data collected by Hall, Jaffe and Trajtenberg (2001) where each citing patent that was granted between 1975 and 1999 is matched to all patents cited by the patent.

\section{Results}

\section{Trends}

Figures $1 \mathrm{~A}, \mathrm{~B}$, and $\mathrm{C}$ show the annual percentage of industry-assigned patents that list at least one inventor who had previously been named an inventor on a universityassigned patent applied for sometime in the previous ten years (UNIV). ${ }^{8}$ Because our data included patents granted in 1975 and later, we imposed a cut-off for the patents used to define whether an inventor was university-experienced at the time of the industry patent's application. We chose to consider only those university-assigned patents on which the inventor appeared in the ten years prior to the date of the industry patent's application because ten years still leaves us a long period over which to conduct our analysis and because skills or knowledge acquired in a university setting far in the past may not be very valuable. Figure 1A shows this measure for all patents granted to U.S. industry assignees by application year for the years 1985 through 1997. Figures 1B and C isolate the pharmaceutical and semiconductor industries, respectively, for the period 1989 through 1997.

Figure 1A shows a steady increase in UNIV between 1985 and 1995, from 0.9 to 2.6 percent. UNIV then drops from 2.6 percent in 1995 to 1.9 percent in 1996 before

\footnotetext{
${ }^{8}$ Our university assignees include domestic universities, hospitals, research laboratories (non-government), and non-profit organizations in the U.S.
} 
recovering somewhat in 1997. This precipitous rise and fall of UNIV is puzzling-we observe this phenomenon in the other figures discussed below—but may be related to a change in patent law in 1995. Until 1995, successful patent applicants received a 17 year monopoly on the use of their invention from the date the patent was granted. For applications filed after June 8, 1995, patented applicants received a 20 year monopoly commencing from the date of the patent application. This new law may have changed the duration of the monopoly for many patent holders, affording longer monopoly periods for patents that are approved quickly, and shorter periods for patents whose review procedure is delayed, as by an appeal or an interference proceeding. In addition, the new law provided that patents applied for prior to June 8, 1995 and issuing on or after June 8 would expire either 17 years from issuance, or 20 years from the date of original application, whichever generated the longer monopoly period (Radack, 1995; Elman, Wilf, and Fried, 1995). These relatively generous terms may have for the short transitional period made some marginal innovations worth the opportunity cost of patenting. The figure in appendix $\mathrm{C}$ shows the patent applications by application year over the period 1985 through 1997. The applications time series show a distinctive blip in 1995 that may reflect a rush to file applications before the June 7 expiration date to take advantage of the opportunity to lock in an extended monopoly period. Moreover, because basic research has a longer shelf life, firms with inventions constituting basic research may have been especially keen to obtain the longer monopoly period. Thus it seems to us natural to see an increase in university influence in our figures during the transition period. ${ }^{9}$

\footnotetext{
${ }^{9}$ Another possibility we considered was a truncation effect. Our data set may exclude some patents applied for in the late 1990s that had not been granted by February 2002, the end date of our data. Thus, if the
} 
Figures $1 \mathrm{~B}$ and $\mathrm{C}$ show the measure UNIV for firms in the pharmaceutical and semiconductor industries, respectively, for the period 1989 through 1997. First, note in this period in both industries an increase in the percentage of patents that name at least one inventor who has invented for university-assigned patents. Second, note that patents in the pharmaceutical industry were more likely than those in the semiconductor industry to include an inventor who had university patent experience: over this period, about 6.6 percent of patents in the pharmaceutical industry included at least one inventor with university patenting experience compared to about 1.9 percent in the semiconductor industry. Also note that the rate of increase was greater for the semiconductor industry. Finally, note the blip centered on 1995 in the pharmaceutical time series, which is absent in the semiconductor time series. For the pharmaceutical industry the length of time of the monopoly may be more important as pharmaceutical patents typically still earn substantial revenues at the end of the monopoly period (Elman et al, 1995), suggesting the deadline may have provoked a greater behavioral response in the pharmaceutical industry.

One concern is that firms may have been interacting with university-experienced inventors in earlier years at the same rate as in later years but because universities infrequently patented before the 1980s we do not detect it. Figure $1 \mathrm{D}$ reports the fraction of inventors with university patenting experience in the last 10 years who appear on industry patents by application year; this measure does not suffer from the aforementioned problem. Figure 1D shows that between 1985 and 1997 the alternative

more complicated patent applications tend also to be the patent applications involving universityexperienced inventors, than our time series might trail off at the end of the period, as depicted in Figure 1A. We tested this hypothesis by using the patent granting dates to truncate the data artificially; we tossed out all patents that had not been granted as of (the arbitrarily chosen year) 1994. This failed to produce a blip leading us to conclude this phenomenon is not caused by truncation. 
measure exhibits similar dynamics, more or less rising through 1995, then falling precipitously.

Figures 2A, B and C show the percentage of industry patents that include at least one inventor with an advanced degree (ADVDEG). Figure 2A shows this figure for all patents granted to U.S. industry assignees. Figures 2B and C show the pharmaceutical and semiconductor industries, respectively. Figure 2A shows a steady increase in ADVDEG from 6.9 percent in 1985 to 13.9 percent 1995, where it dips slightly in 1996, and then begins to rise again, reaching 14.7 percent in 1997. ADVDEG averages 33 percent for the pharmaceutical industry and 19 percent for the semiconductor industry. This indicates that both industries are especially reliant on highly-educated labor for research as the averages in both industries are higher than the overall average in the full data set during the same period. Figures $2 \mathrm{~B}$ and $\mathrm{C}$ confirm the findings in Figures $1 \mathrm{~B}$ and $\mathrm{C}$ in that (1) both time series increase through the period, (2) the level is higher in the pharmaceutical industry, but the rate of increase is higher for the semiconductor industry, and (3) the time series for the pharmaceutical industry demonstrate a blip centered at 1995.

Similar to Figure 1D, Figure 2D reports the number of inventors named in industry patents with advanced degrees (in science and engineering awarded by U.S. and Canadian universities within the last 20 years) by application year as a percentage of the stock of inventors holding advanced degrees. ${ }^{10}$ We produce Figure 2D because we are concerned that the upward trend in the percentage of patents that name inventors with advanced degrees is only a consequence of the fact that there are more inventors with

\footnotetext{
${ }^{10}$ Ideally we would like the stock of degree holders who are still in the labor market. Due to data availability, however, we use the stock of degrees awarded in the last 20 years.
} 
advanced degrees. The measure in Figure 2D attempts to capture how active firms are in recruiting inventors with advanced degrees. This measure exhibits a similar pattern as the measure in Figure 1D, rising over the period of 1985 and 1997, with a hump, albeit small, in 1995.

Figures 3A, B, and C show the annual percentage of industry-assigned patents that cite as prior art a university patent applied for within the previous ten years (UCITE). Figure 3A displays UCITE for all industries for the period 1985 through 1997. Figures 3B and C display UCITE for the pharmaceutical and semiconductor industries, respectively. Figure 3A shows a steady increase in UCITE between 1985 and 1995, from 3.1 percent to 8.4 percent, followed by a decline through the end of the period. Qualitatively, Figures 3B and C display similar patterns to those displayed by Figures 1B and C and 2B and C: UCITE's average level is higher for the pharmaceutical industry and in both industries UCITE rises over time. In both industries, UCITE peaks in 1995, but the drop off is more striking in the pharmaceutical industry. Figures $3 \mathrm{~B}$ and $\mathrm{C}$ show an approximately two-fold increase in the relative importance of university patents in both industries.

Firms may have been influenced by university research in earlier years, but because university research was patented at lower rates industry access was not as apparent. Thus we create a measure of the likelihood that a university patent is cited by industry. Figure 3D shows the percentage of 10-year old and younger university patents that are cited, by application year. Like UCITE, this new measure generally increases from 1985 through 1995, after which it falls precipitously. 


\section{Decomposition of university influence}

An increase in the presence of university-experienced persons among the firm's inventors results either from an increase in their representation in the pool of available scientific personnel from which it (perhaps randomly) hires, or from an increase in the firm's propensity to hire such workers. In fact, the purpose of Figures 1D, 2D and 3D is to show a time trend in the contribution of the latter factor. While both of these factors mix elements of demand and supply, measuring their separate contributions is still informative of the channels through which the changes are operating. Thus in this section, we attempt to decompose the change in university influence into components representing various factors, including these two.

We decompose an increase over our entire sample period in industry patents with university-experienced inventors in the following way.

$$
\mathrm{U}_{\mathrm{t}}=\left(\mathrm{U}_{\mathrm{t}} / \mathrm{I}_{\mathrm{t}}\right)\left(\mathrm{I}_{\mathrm{t}} / \mathrm{M}_{\mathrm{t}}\right)\left(\mathrm{M}_{\mathrm{t}} / \mathrm{P}_{\mathrm{t}}\right) \mathrm{P}_{\mathrm{t}} \text {, }
$$

where $U_{t}$ denotes the number of industry patents in year $t$ that have at least one inventor with university patent experience in the last 10 years, $I_{t}$ denotes the number of inventors of industry patents in year $t$ with university patent experience, $M_{t}$ denotes the number of all inventors that appear in university patents in the last 10 years, and $\mathrm{P}_{\mathrm{t}}$ denotes the number of industry patents in year t.

Taking the logarithm of both sides of equation (1) and taking the difference between year s and $\mathrm{t}$, we have

$$
\begin{aligned}
\log \mathrm{U}_{\mathrm{s}}-\log \mathrm{U}_{\mathrm{t}} & =\left[\log \left(\mathrm{U}_{\mathrm{s}} / \mathrm{I}_{\mathrm{s}}\right)-\log \left(\mathrm{U}_{\mathrm{t}} / \mathrm{I}_{\mathrm{t}}\right)\right]+\left[\log \left(\mathrm{I}_{\mathrm{s}} / \mathrm{M}_{\mathrm{s}}\right)-\log \left(\mathrm{I}_{\mathrm{t}} / \mathrm{M}_{\mathrm{t}}\right)\right] \\
& +\left[\log \left(\mathrm{M}_{\mathrm{s}} / \mathrm{P}_{\mathrm{s}}\right)-\log \left(\mathrm{M}_{\mathrm{t}} / \mathrm{P}_{\mathrm{t}}\right)\right]+\left[\log \mathrm{P}_{\mathrm{s}}-\log \mathrm{P}_{\mathrm{t}}\right]
\end{aligned}
$$


This equation illustrates that the change in $U_{t}$ is the sum of the changes in (a) the patent productivity of university-experienced inventors in industry $\left(\mathrm{U}_{\mathrm{t}} / \mathrm{I}_{\mathrm{t}}\right)$, (b) the probability that university patent inventors later appear in industry patents $\left(\mathrm{I}_{\mathrm{t}} / \mathrm{M}_{\mathrm{t}}\right)$, (c) the average number of university inventors available for an industry patent $\left(\mathrm{M}_{\mathrm{t}} / \mathrm{P}_{\mathrm{t}}\right)$, and (d) the number of industry patents $\left(\mathrm{P}_{\mathrm{t}}\right)$. The second ratio $\left(\mathrm{I}_{\mathrm{t}} / \mathrm{M}_{\mathrm{t}}\right)$ can be loosely interpreted as an indicator of firms' propensity to hire university-experienced inventors (shown in Figure 1D) while the third ratio $\left(\mathrm{M}_{t} / \mathrm{P}_{t}\right)$ as a measure of the prevalence of university-experienced inventors in the pool of inventive talent. ${ }^{11}$

In a similar fashion, we can decompose an increase in industry patents with advanced-degree holding inventors. In this case, $\mathrm{U}_{\mathrm{t}}$ is the number of industry patents in year $t$ that have at least one inventor with an advanced degree, $I_{t}$ is the number of inventors with advanced degrees on industry patents in year $t$, and $\mathrm{M}_{\mathrm{t}}$ is defined as the stock of inventors in year t holding advanced degrees (see footnote 10).

In decomposing an increase in industry patents that cite university patents, $U_{t}$ denotes the number of industry patents that cite university patents granted within the last 10 years, $\mathrm{I}_{\mathrm{t}}$ denotes the number of unique university patents cited, and $\mathrm{M}_{\mathrm{t}}$ denotes the stock of 10-year old and younger university patents citable.

Figure 4 presents the decompositions of the increase in industry patents that name inventors with university patents in their past, that name inventors with advanced degrees, and that cite university patents. In examining these three decompositions, one sees that the increase in patenting during the sample period explains much of the increase in these variables, as one would expect. Because we are interested ultimately in

\footnotetext{
${ }^{11}$ We were unable to perform the decomposition exercise separately for our two industries because the number of inventors that appear in university patents in the pharmaceutical or semiconductor field (that is $\mathrm{M}_{\mathrm{t}}$ ) is not available.
} 
understanding better the dynamics of $\mathrm{U} / \mathrm{P}$, however, we focus the discussion on the other explanatory factors.

Consider first decomposition (a). An increase in $\mathrm{M} / \mathrm{P}$ - the stock of inventors with university patenting experience relative to the flow of patents-explains most of the increase in the number of industry patents naming university experienced inventors that is not explained by P. Note also that decomposition (c) shows that the increase in industry patents that cite university patents is largely driven by the growth in the stock of university assigned patents that is available to cite. Thus, both the increase in UNIV and in UCITE appears to be driven by the growth in university patents. The increased likelihood of an inventor with university patenting experience appearing on a patent does, however, explain some of the growth in UNIV. Finally, the increased likelihood of an inventor with an advanced degree appearing on an industry patent is the largest factor in the growth of patents naming inventors with an advanced degree (decomposition b). The size of the available group of inventors with advanced degrees per industry patent actually fell over the sample period. In all cases of decomposition, the change in the patent productivity term (U/I) had a minimal explanatory power in the patent increase.

\section{Determinants of university influence}

We are interested in learning which firms access university research. For example, are there scale or scope economies in exploiting university research that favor large or diversified firms? Do young firms that are developing and using new technologies make greater use of university research than older firms? Tables 2, 3, and 4 present the results of our estimation of the determinants of accessing university research. 
These regressions relate measures of the firm's access to university research in year $t$ and firm characteristics. The dependent variables in Tables 2, 3, and 4 are the logit transform of the fractional form of the variables defined in Figures 1, 2, and 3, that is, of UNIV, ADVDEG, and UCITE, respectively. We should note, however, that these variables in our regressions are defined at the firm level, not at the economy or industry level. All models are estimated with random (firm) effects.

The means and standard deviations of the independent and dependent variables, along with their definitions, are described in Table $1 .{ }^{12}$ All right-hand side variables are logged. The base specification includes a measure of the size of the research operation, proxied by the number of inventors of patents (INVENTOR), to examine the effect of economies of scale at the R\&D enterprise level. Alternatively, we use the number of employees (EMPLOYEE) as a measure of organizational size at the firm level. The base specification also includes the R\&D-inventor ratio (R\&D/INV) and the number of business lines in the firm (NSIC), measured by the number of secondary SIC's identified with the firm. We include the R\&D-inventor ratio $(\mathrm{R} \& \mathrm{D} / \mathrm{INV})$ as a regressor because a highly capitalized firm may rely on more advanced technology, which may be reflected in the nature of its innovation, or lead the firm to use skilled labor more intensively (see Griliches, 1969, Goldin and Katz, 1998, for evidence on capital-skill complementarity). We include NSIC as a regressor to estimate the impact of economies of scope on how a firm's reliance on university-originated research.

\footnotetext{
${ }^{12}$ Note that the means of the patent percentages in the figures for the two industries are not equal to those reported in Table 1 because in Table 1 we average the percentages of patents for firms in each industry while the figures show the total number of university-influenced patents in an industry as a ratio to the total number of patents assigned to the industry.
} 
The results for the basic specification are included in the first column of each panel. They consistently show a positive effect of size of the R\&D enterprise on the use of inventors with university patenting experience (Table 2) and on the use of inventors with advanced degrees (Table 3), in both industries. The size of the R\&D enterprise also increases the likelihood that a firm's patents cited university-assigned patents. On the other hand, the size at the firm level shows no effect on the use of university research: EMPLOYEE has insignificant effects in all tables. The coefficient estimate on $\operatorname{logR} \& \mathrm{D} / \mathrm{INV}$ is generally positive but insignificant in all regressions. The coefficient estimate on log NSIC is never significant by conventional criteria of significance.

The second column in each panel describes the results from estimations that include two additional regressors: median experience of all inventors in a firm (MEXP) and years elapsed since the founding year of a firm (FIRMAGE). These variables are excluded from our base specification because we lack these data for many firms in our sample. The coefficient estimate on log MEXP is positive and significant for both industries for the UNIV regressions. This may partly reflect that inventors who are more experienced are also more likely to have invented for a university assignee. We also observe a positive but insignificant relationship between median experience and ADVDEG or UCITE. The coefficient estimate on log FIRMAGE is negative in most cases and is negative and significant in the pharmaceutical regressions with UNIV as the dependent variable. That is, we find evidence that older firms in the pharmaceutical industry employ fewer inventors with university patenting experience. The marginal effects of the regressors in the second column are reported in Table 5. 
The key variables in our estimation may be time trended, in which case the estimated effect of our independent variables on our measures of university research influence could be spurious. To test the sensitivity of our result to a time trend effect, we introduce the time trend as an additional right-hand side variable. These results are reported in the third column of each panel. The addition of a time trend does not generally change the inference; where coefficient estimates are significant in the time trend's absence, they are significant in its presence.

Does the presence of university-experienced scientists in the firm increase the firm's ability to access university research? Or, do firms with more universityexperienced inventors produce more patents that cite university patents? Table 6 addresses the question on the mechanisms of spillovers. The first two columns for each industry panel show the estimates of the determinants of the firm's citing of at least one university patent (ANYUCITE is the binary dependent variable). The results reported are from a random-effects probit model. The next two columns report the estimates of the determinants of the number of the firm's patents that cite university patents (UCITE is the dependent variable). The results reported are from a random-effects regression model. The key regressors in this table are binary variables for whether a firm has at least one university-experienced inventor (ANYUSCI) or at least one inventor with an advanced degree (ANYPHD).

The results in Table 6 show that firms with more university-experienced inventors in both industries are more likely to have patents that cite university patents: ANYUSCI has a significantly positive effect in both models. Having inventors with advanced 
degrees is not shown to lead to more citations to university patents, as ANYPHD has an insignificant, albeit positive, effect.

\section{Conclusion}

Our results suggest that economy-wide and in the pharmaceutical and semiconductor industries individually, industry's use of inventors with past experience conducting university research, and of inventors with advanced degrees, has increased. This may mean that R\&D-doing firms have increased their access to university-produced knowledge through the knowledge imbedded in inventors' human capital. That industry is making greater use of university-produced knowledge is also reflected in the citation data. Economy-wide and in the pharmaceutical and semiconductor industries individually we observe an increase in the citing of university patents. Using our inventor-based measures, we find a faster increase in access to university research in the semiconductor industry. Using the citation-based measure, we find roughly equivalent increases. The pharmaceutical industry shows greater access to university research (by any of our three measures) than the semiconductor industry.

The decomposition offers additional insight into the increase in industrial patents' naming of inventors with university patenting experience and with advanced degrees, and industrial patents' citing of university patents. First, the growth in university patenting may explain most of the increase in the fraction of industry patents that name inventors with university patenting experience and the fraction of industry patents that cite university patents—at least at the level of the economy. The increased likelihood of an inventor with university patenting experience appearing on a patent does, however, 
explain some of the growth of industry patents by inventors with university patenting experience. The increase in the fraction of industry patents that name inventors with advanced degrees appears to be almost entirely due to the likelihood of inventors with advanced degrees appearing on industry patents (i.e., it is not due to an increase in the stock of inventors with advanced degrees).

In our firm-level analyses, we find that firms with large research operations are more likely to access university research than firms with small ones. Pharmaceutical firms with higher R\&D-inventor ratios are more likely to utilize inventors on their patents who had previous university research experience. Firms in both industries with more experienced inventors were more likely to utilize inventors with university research experience. Younger pharmaceutical firms were more likely to utilize inventors with university research experience. Finally, we find evidence that employing scientists with university research experience may better enable firms to access university-produced knowledge. Specifically, we find that inventors with university patenting experience increases the extent that the patents of a firm cite university patents as prior art.

Needless to say, we recognize a number of shortcomings in our analysis that we plan to address in future work. For example, our name matching procedure undoubtedly is subject to error, sometimes treating different inventors as a single inventor, and other times treating the same inventor as different inventors. These matching errors are likely more important in the analysis of levels of involvement with university research, as opposed to the analysis of trends. Nonetheless future work will attempt alternative matching rules for the sensitivity of our findings. 
An interesting question which is not investigated in this paper is how the use of university research affects the productivity of $R \& D$ in firms. Another interesting question is how start-up firms utilize university research. In future work, we plan to explore theses issues. 


\section{Appendix A. SOUNDEX coding system}

A SOUNDEX code for a surname is an upper case letter followed by 6 digits. For example the SOUNDEX code for Kim is K500000, while that for Marschke is M620000. The first letter is always the first letter of the surname. The rules for generating a SOUNDEX code are:

1. Take the first letter of the surname and capitalize it.

2. Go through each of the following letters giving them numerical values from 1 to 6 if they are found in the Scoring Letter table (1 for B, F, P, V; 2 for C, G, J, K, Q, S, X, Z; 3 for D, T; 4 for L; 5 for M, N; 6 for R; 0 for Vowels, punctuation, H, W, Y).

3. Ignore any letter if it is not a scoring character. This means that all vowels as well as the letters $\mathrm{h}, \mathrm{y}$ and $\mathrm{w}$ are ignored.

4. If the value of a scoring character is the same as the previous letter then ignore it. Thus if two 't's come together in the middle of a name they are treated exactly the same as a single ' $t$ ' or a single ' $d$ '. If they are separated by another non-scoring character then the same score can follow in the final code. The name PETTIT is P330000. The second ' $\mathrm{T}$ ' is ignored but the third one is not since a nonscoring 'I' intervenes.

5. Add the number onto the end of the SOUNDEX code if it is not to be ignored.

6. Keep working through the name until you have created a code of 6 characters maximum.

7. If you come to the end of the name before you reach 6 characters, pad out the end of the code with zeros.

8. Optionally you can ignore a possessive prefix such as 'Von' or 'Des'.

See "Using the Census SOUNDEX," General Information Leaflet 55 (Washington, DC: National Archives and Records Administration, 1995) for the detailed method.

\section{Appendix B. Problem of Transitivity}

Imposing transitivity can create a possibility of name mismatch in that two inventors with different middle names are matched.

We found, however, that there are a trivial number of inventors with this problem: 126 inventors out of 2.3 million uniquely identified inventors. Upon further investigation of these cases, we found they are typically due to the following three reasons. First, some 
middle names in the Patent BIB data are incorrectly coded. For instance, our transitivity procedure matched inventors named Laszlo Andra Szporny and Laszlo Eszter Szporny, but we found that these two are the same inventor without middle name and those middle names are in fact the first names of the next co-inventors in their patents. Second, an inventor with two middle names is coded in the Patent BIB data with one middle name in some cases and with the other middle name in other cases. The only case that can be apparently identified as a mismatch is that when two inventors with the same last and first name but different middle names appear in the same patent. However, it is not simple to separate them because it can be rather arbitrary. For example, we can either assign the records of Adam Smith to Adam J. Smith or Adam E. Smith.

\section{Appendix C. Number of Patent Applications}

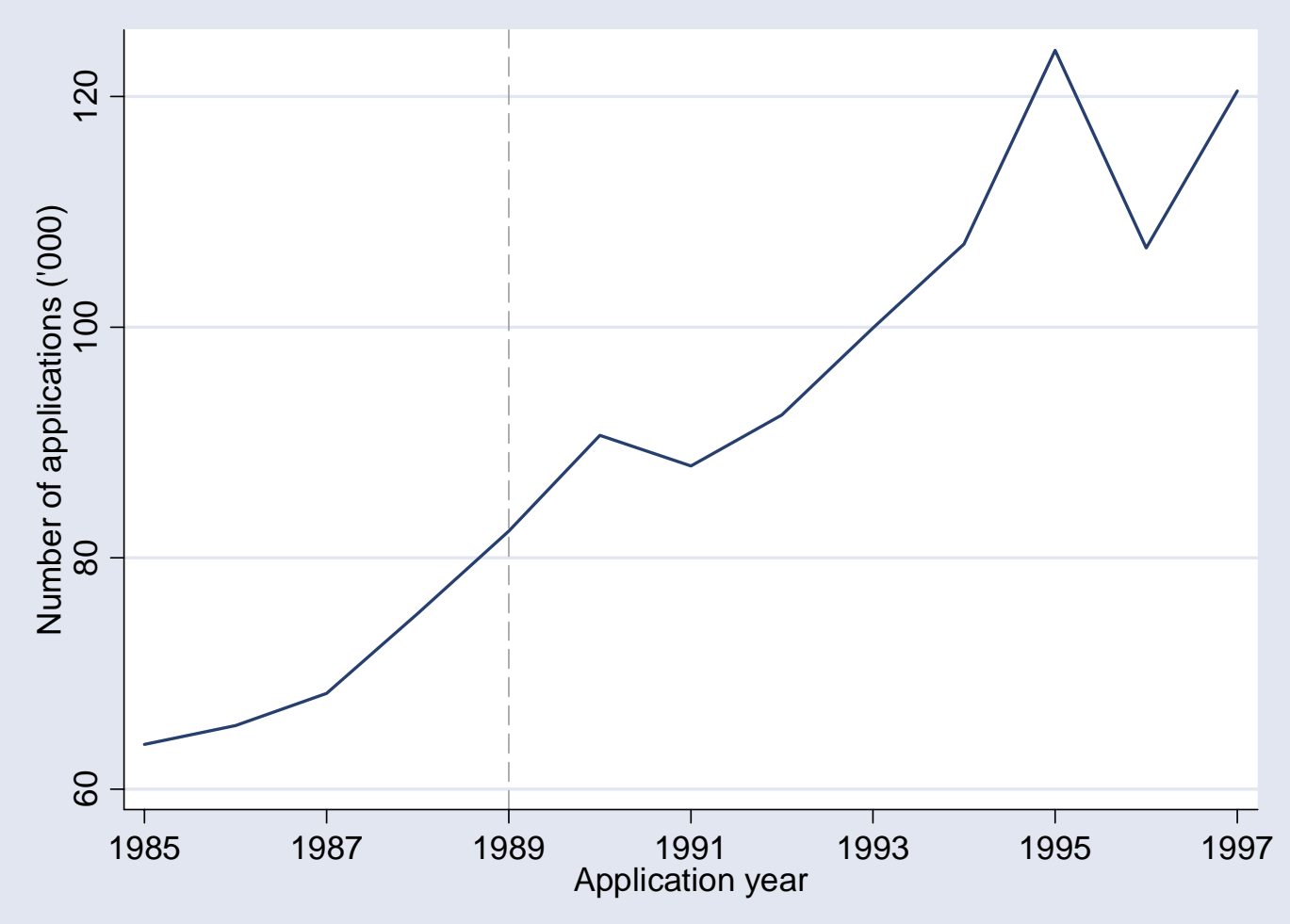




\section{References}

Adams, James D. 1990. "Fundamental Stocks of Knowledge and Productivity Growth.” The Journal of Political Economy, 98(4), pp. 673-702.

Agrawal, Ajay K., Cockburn, Iain M., and McHale John 2003 "Gone but Not Forgotten: Labor Flows, Knowledge Spillovers, and Enduring Social Capital,” NBER Working Paper no. 9950

Cockburn, Iain M. and Henderson, Rebecca M. 1998. "Absorptive Capacity, Coauthoring Behavior, and the Organization of Research in Drug Discovery." The Journal of Industrial Economics, 46(2), pp. 157-182.

Cohen, Wesley M., Nelson, Richard R., and Walsh, John P. 2000. "Protecting Their Intellectual Assets: Appropriability Conditions and Why U.S. Manufacturing Firms Patent (or Not),” NBER Working Paper no. 7552

Cohen, Wesley M., Nelson, Richard R., Walsh, John P. 2002. "Links and Impacts: The Influence of Public Research on Industrial R\&D.” Management Science, 48(1), pp. 1-23

Elman, Wilf, and Fried. 1995. "The Impact of GATT on Patent Tactics," 'Electric Law Library, http://www.lectlaw.com/files/inp03.htm

Goldin, Claudia and Katz, Lawrence, 1998. "The Origins of Technology-Skill Complementarity,” Quarterly Journal of Economics, 113, pp. 693-732.

Griliches, Zvi, 1969. "Capital-Skill Complementarity,” Review of Economics and Statistics, 51, pp. 465-468.

Hall, B., Jaffe, A. and Trajtenberg, M. "Market Value and Patent Citations: A First Look.” NBER Working Paper No. 7741, 2000.

Hicks, Diana, Breitzman, Tony, Olivastro, Dominic and Hamilton, Kimberly, "The Changing Composition of Innovative Activity in the US--A Portrait Based on Patent Analysis.” Research Policy, 30 (4), 2001, p 681-703.

Jaffe, Adam B. 1989. "Real Effects of Academic Research." The American Economic Review, 79(5), pp. 957-970.

Jaffe, Adam B. and Trajtenberg, Manuel. 1992. "Flows of Knowledge from Universities and Federal Laboratories: Modeling the Flow of Patent Citations over Time," in Patents, Citations, and Innovations: A Window on the Knowledge Economy, Jaffe, Adam B. and Trajtenberg, Manuel, eds. Cambridge, Massachusetts: The MIT Press. 
Kim, Jinyoung and Marschke, Gerald, 2005, "Labor Mobility of Scientists, Technological Diffusion, and the Firm's Patenting Decision," The Rand Journal of Economics, forthcoming, 2005.

Mansfield, E., 1991. "Academic research and industrial innovation.” Research Policy, 20(1), pp. 1-12.

Mansfield, E., 1998. "Academic research and industrial innovation: An update of empirical findings.” Research Policy, 26 (7-8), pp. 773-776.

Moen, Jarle. (2005) "Is Mobility of Technical Personnel a Source of R\&D Spillovers?," Journal of Labor Economics, 23(1), pp. 81-114.

Mowery, David C. and Ziedonis, Arvids Alexander, "The Geographic Reach of Market and Non-Market Channels of Technology Transfer: Comparing Citations and Licenses of University Patents" (October 2001). NBER Working Paper No. W8568.

Narin, Francis, Hamilton, Kimberly S. and Olivastro, Dominic, 1997. "The increasing linkage between U.S. technology and public science,” Research Policy, 26, pp. 317-330.

Nelson, Richard R, Nathan Rosenberg (1993), “Technical Innovation and National Systems”, in R. R. Nelson ed., National Systems of Innovation. A Comparative Analysis. Oxford University Press: Oxford, pp. 3-21.

Parr, Russell L. and Sullivan, Patrick H. Technology Licensing: Corporate Strategies for Maximizing Value, John Wiley \& Sons, Inc, New York, NY, 1996.

Polanyi, Michael. Personal Knowledge: Towards a Post-Critical Philosophy (University of Chicago Press, Chicago, 1958)

Radack, David V. 1995. "GATT Brings Major Changes in U.S. Patent Law," JOM, 47(5), p. 79

Sampat, Bhaven N., Mowery, David C., and Ziedonis, Arvid A. 2003 "Changes in University Patent Quality after the Bayh-Dole Act: A Re-Examination,” Working paper, Georgia Institute of Technology.

Trajtenberg, Manuel, "The Names Game: Using Inventors Patent Data in Economic Research,” Working paper, 2004.

Trajtenberg, Manuel. "A Penny for Your Quotes: Patent Citations and the Value of Innovations.” The Rand Journal of Economics. Vol. 21, No. 1, pp. 172-87, Spring 1990.

Zucker, Lynne G.; Darby, Michael R.; Armstrong, Jeff S. “Commercializing Knowledge: University Science, Knowledge Capture, and Firm Performance in Biotechnology" NBER Working Paper No. 8499, October 2001 
Zucker, Lynne G.; Darby, Michael R.; and Brewer Marilynn B. "Intellectual Human Capital and the Birth of U.S. Biotechnology Enterprises" The American Economic Review, Vol. 88, No. 1. (Mar., 1998), pp. 290-306. 
Figure 1 Patents by Inventors with University Patent Experience

A. All Industries

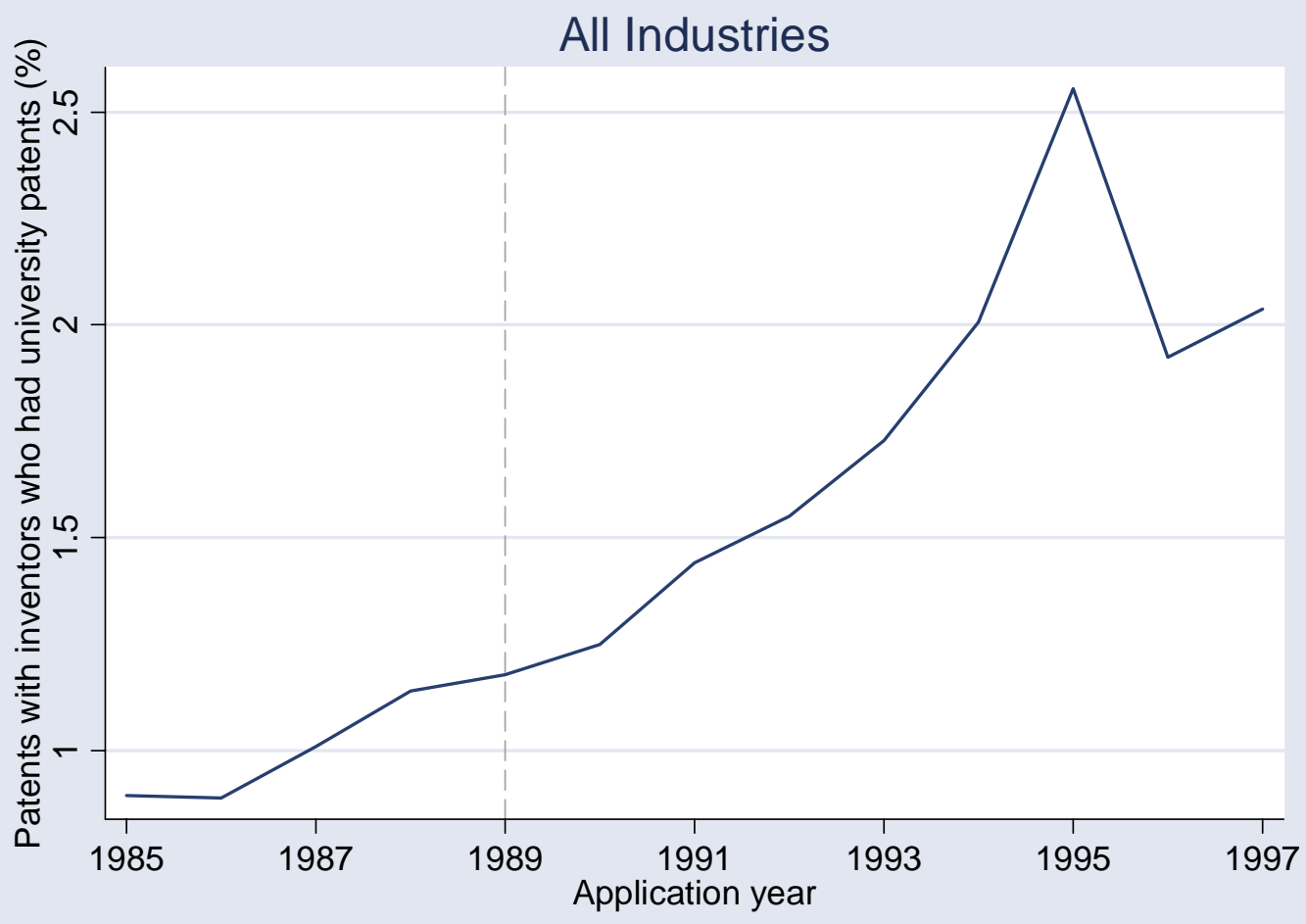

B. Pharmaceutical Industry

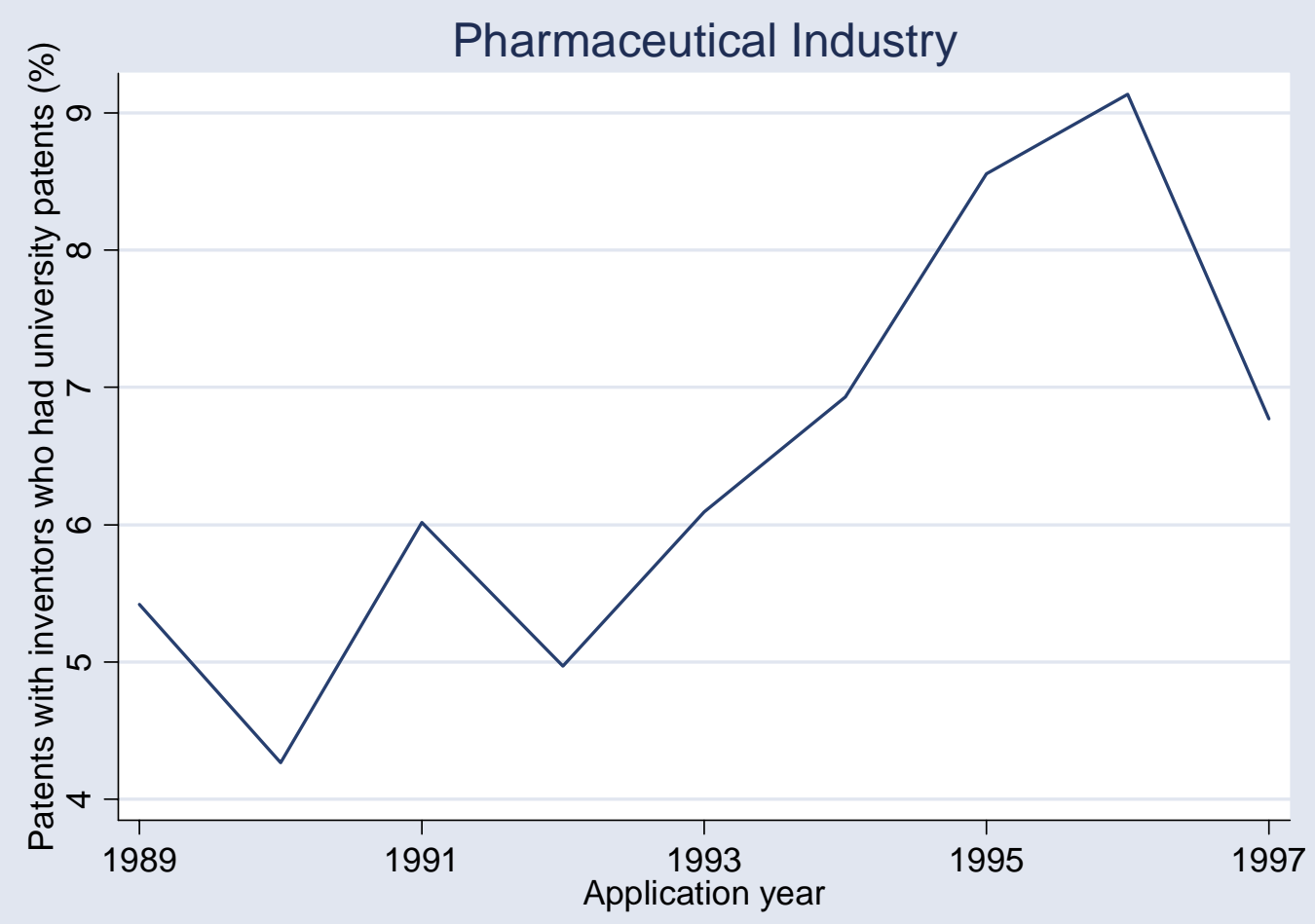


Figure 1 (continued)

C. Semiconductor Industry

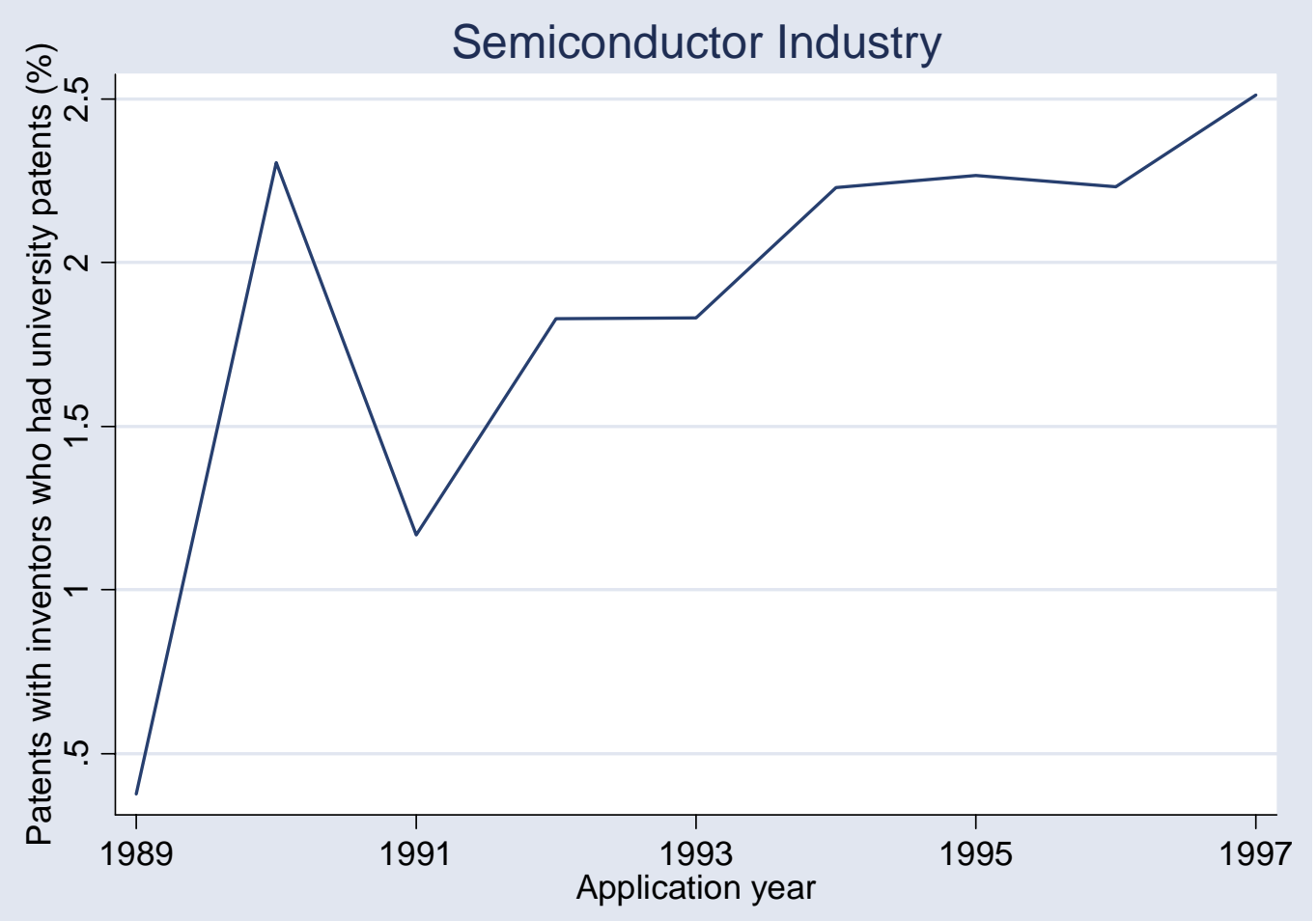

D. Inventor Ratio for All Industries

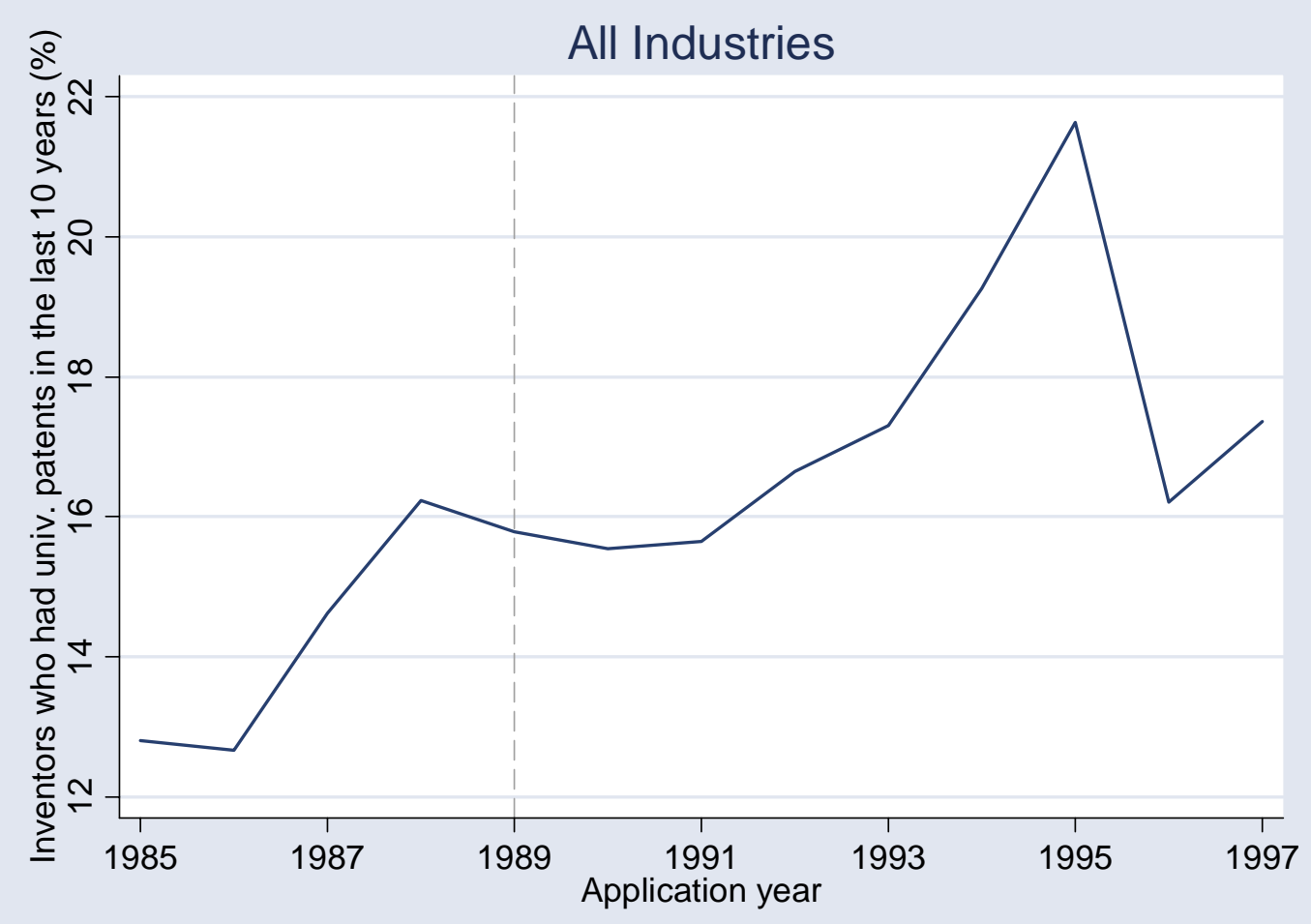


Figure 2 Patents by Inventors with Advanced Degrees

A. All Industries

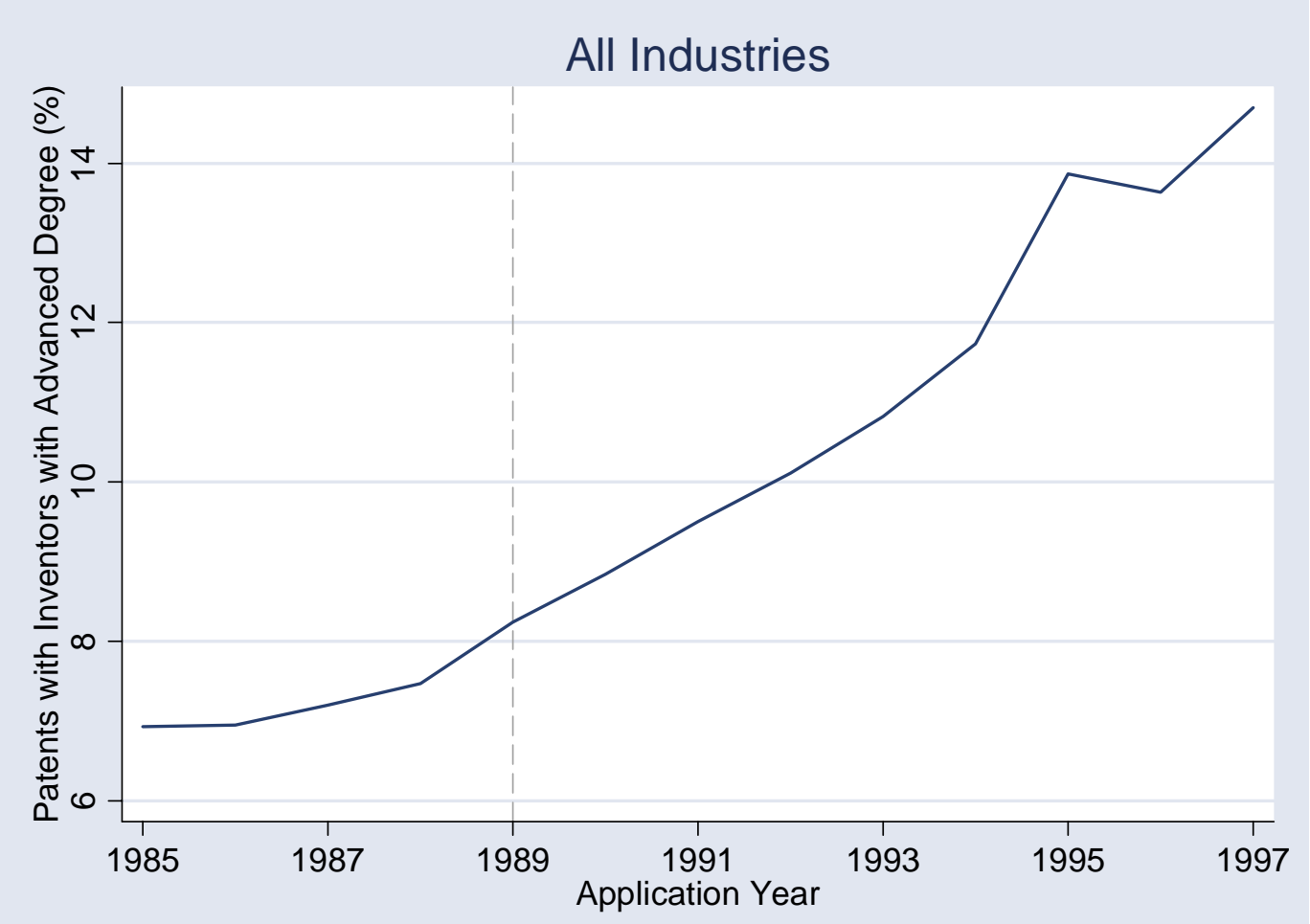

B. Pharmaceutical Industry

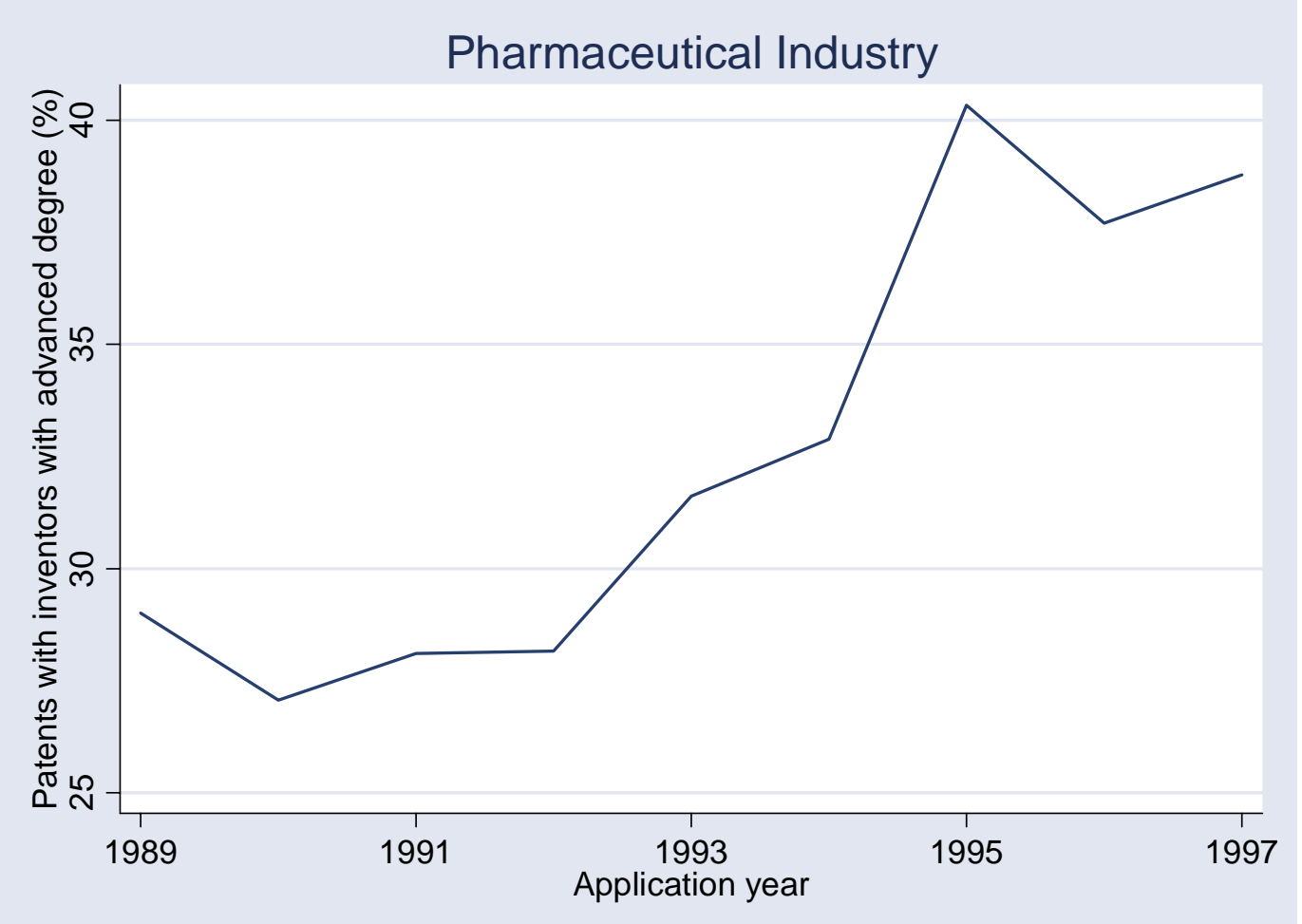


C. Semiconductor Industry

Figure 2 (continued)

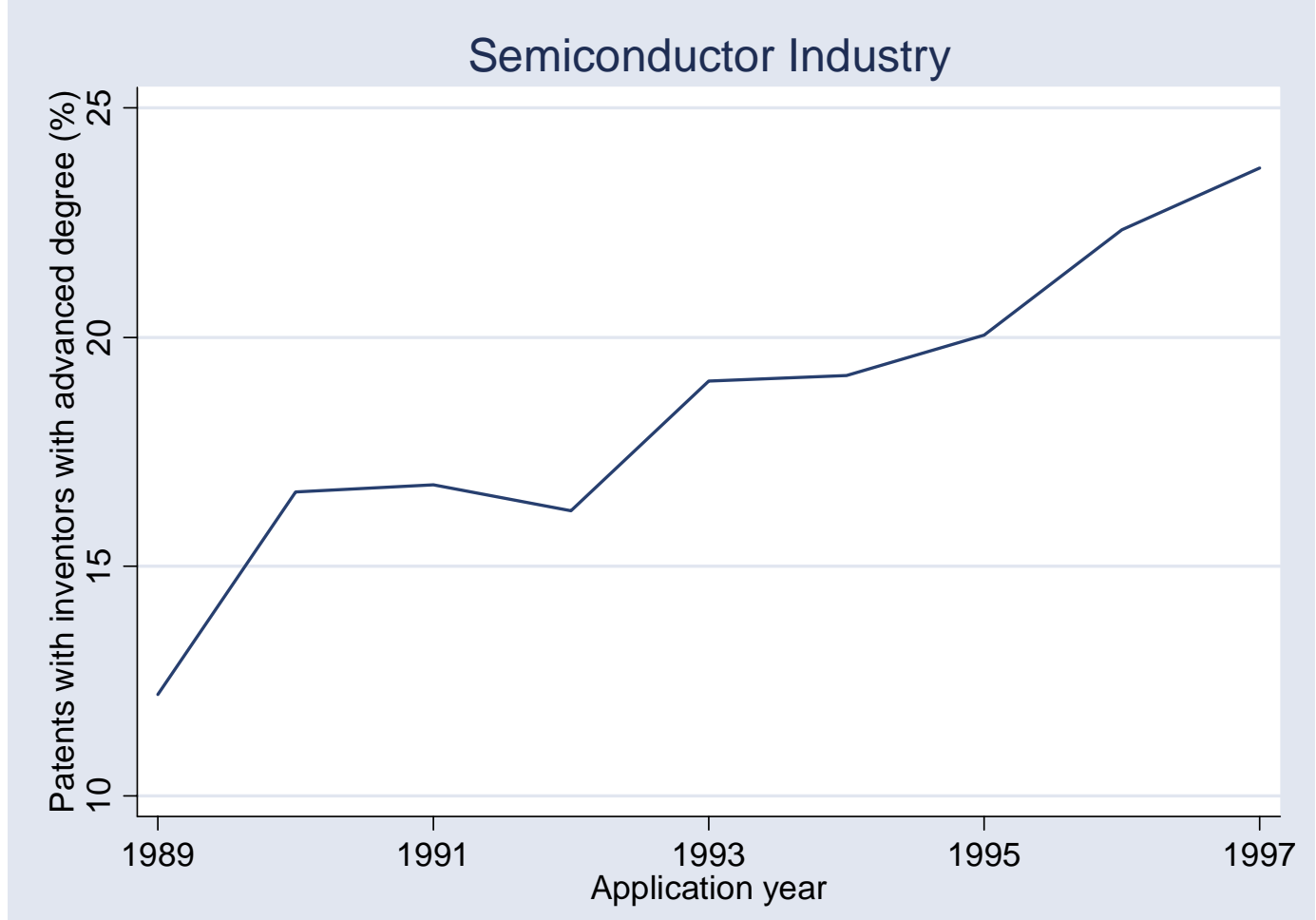

D. Inventor Ratio for All Industries

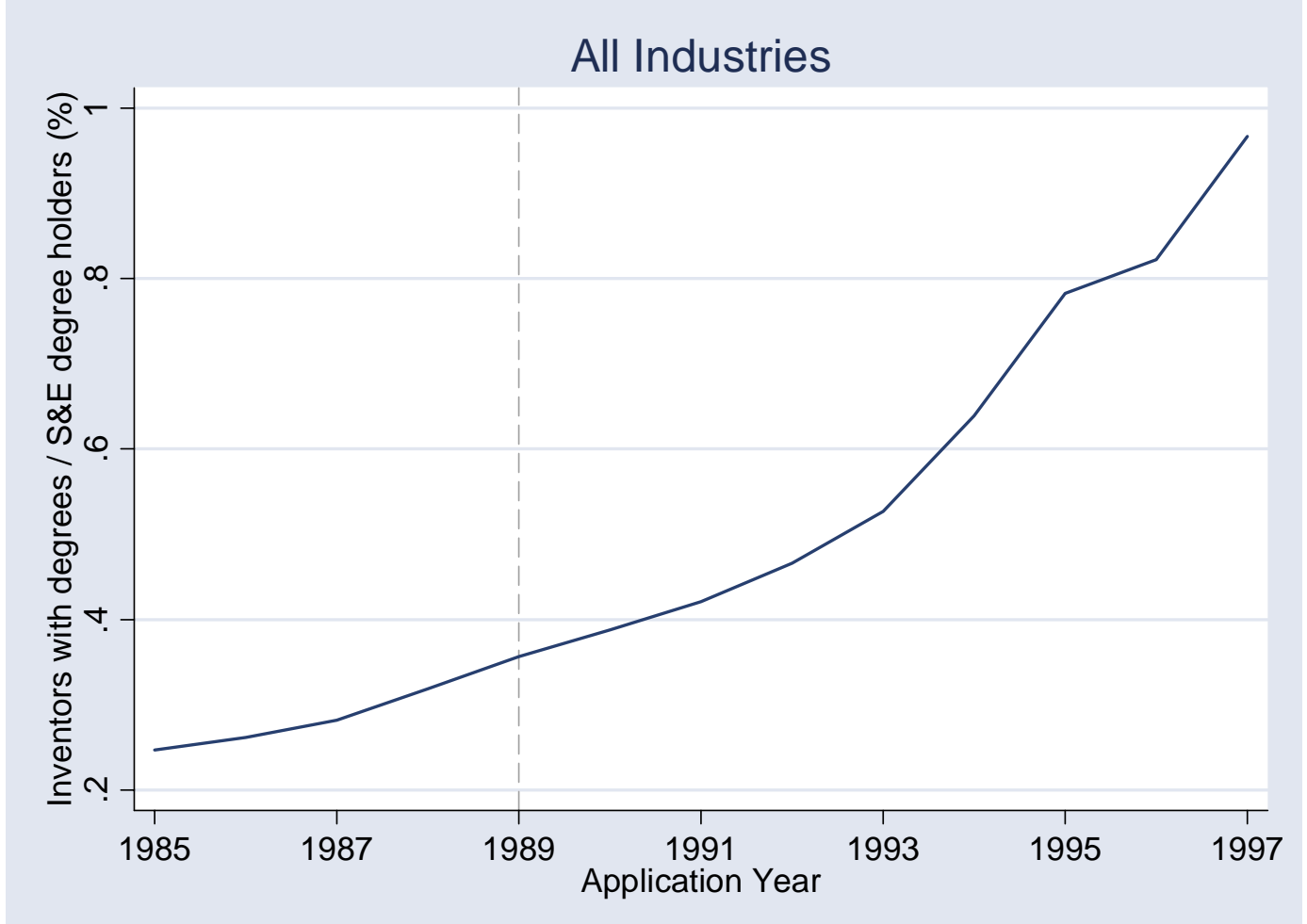


Figure 3 Patents with Citations to University Patents

A. All Industries

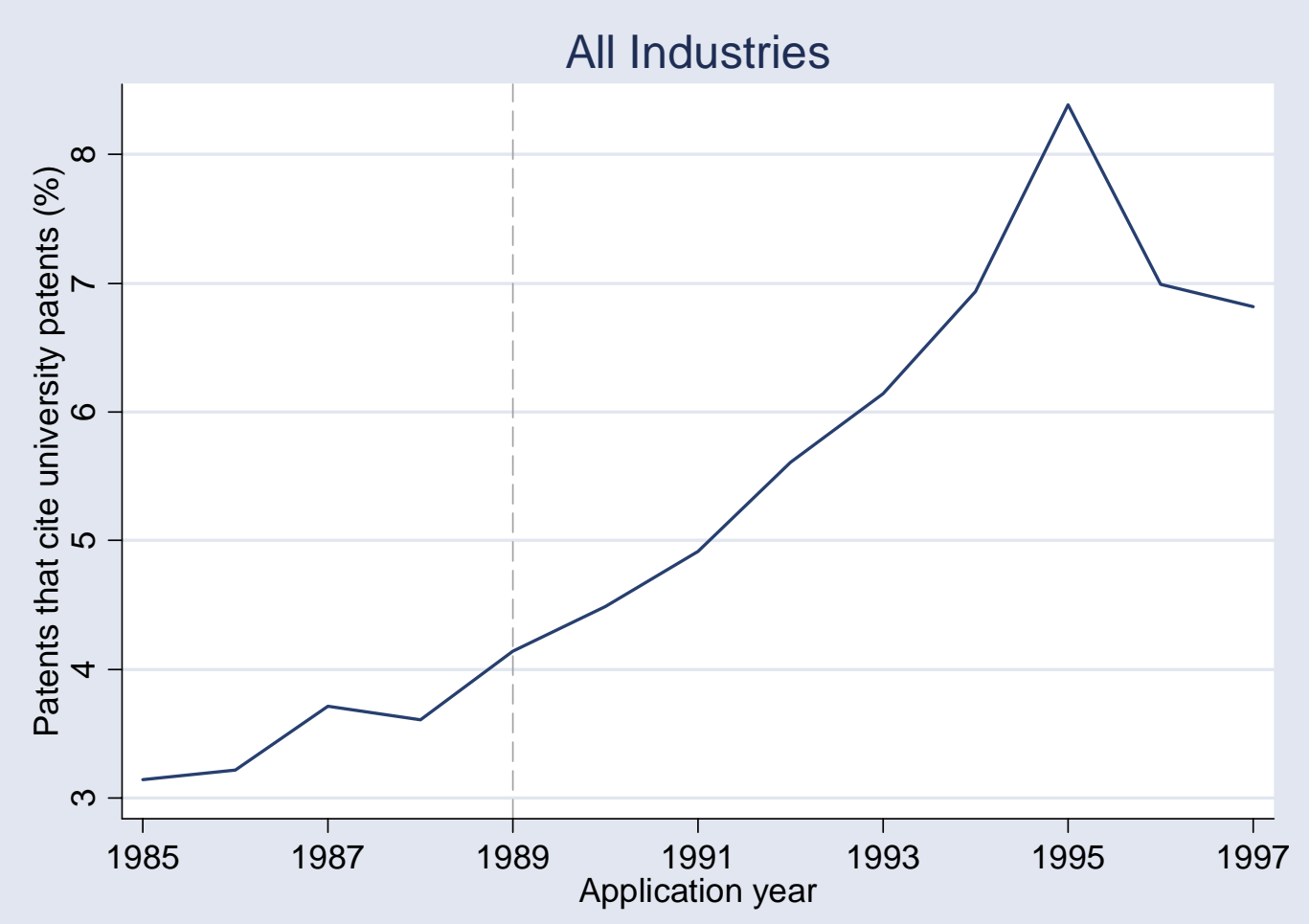

B. Pharmaceutical Industry

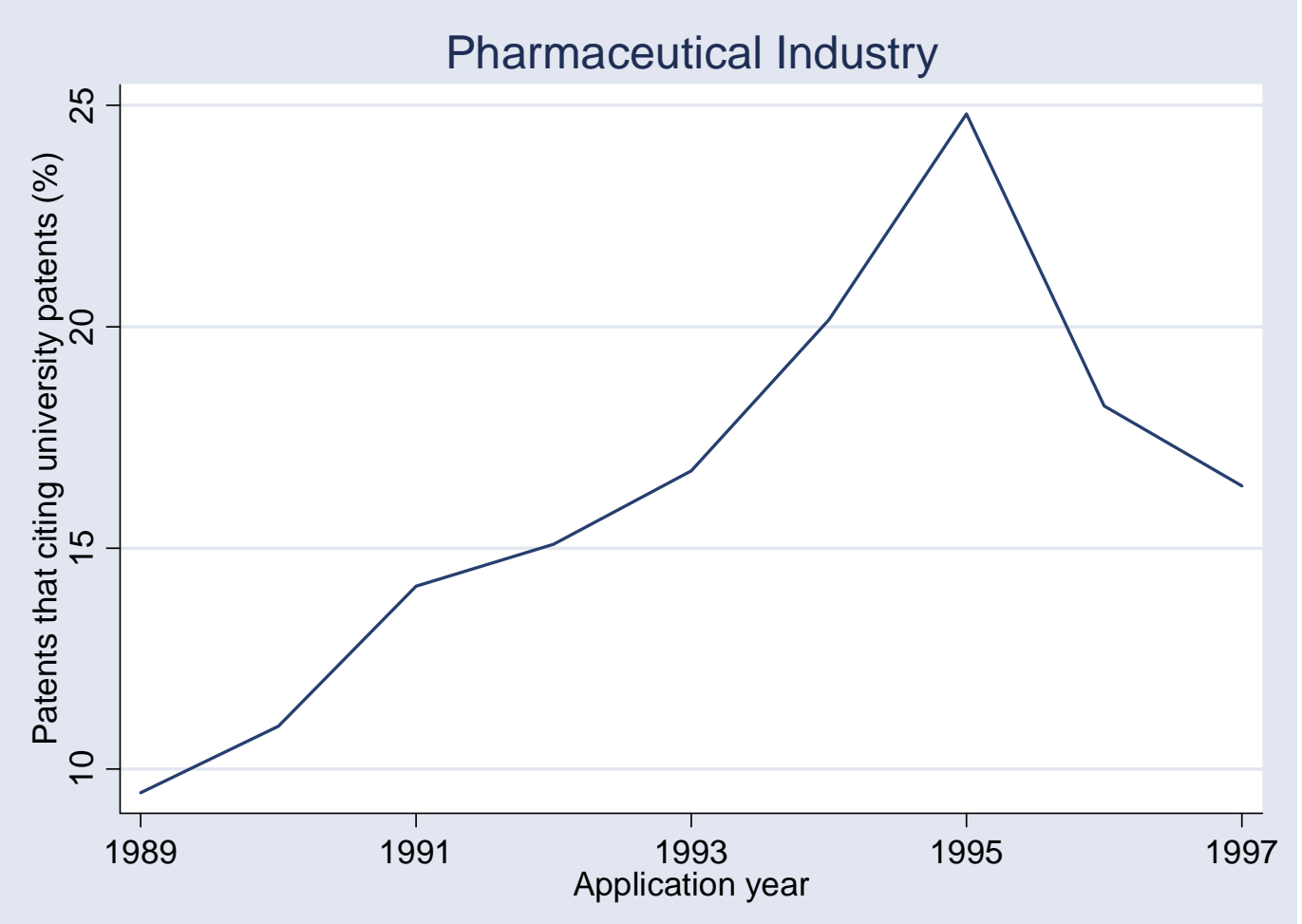


C. Semiconductor Industry

Figure 3 (continued)

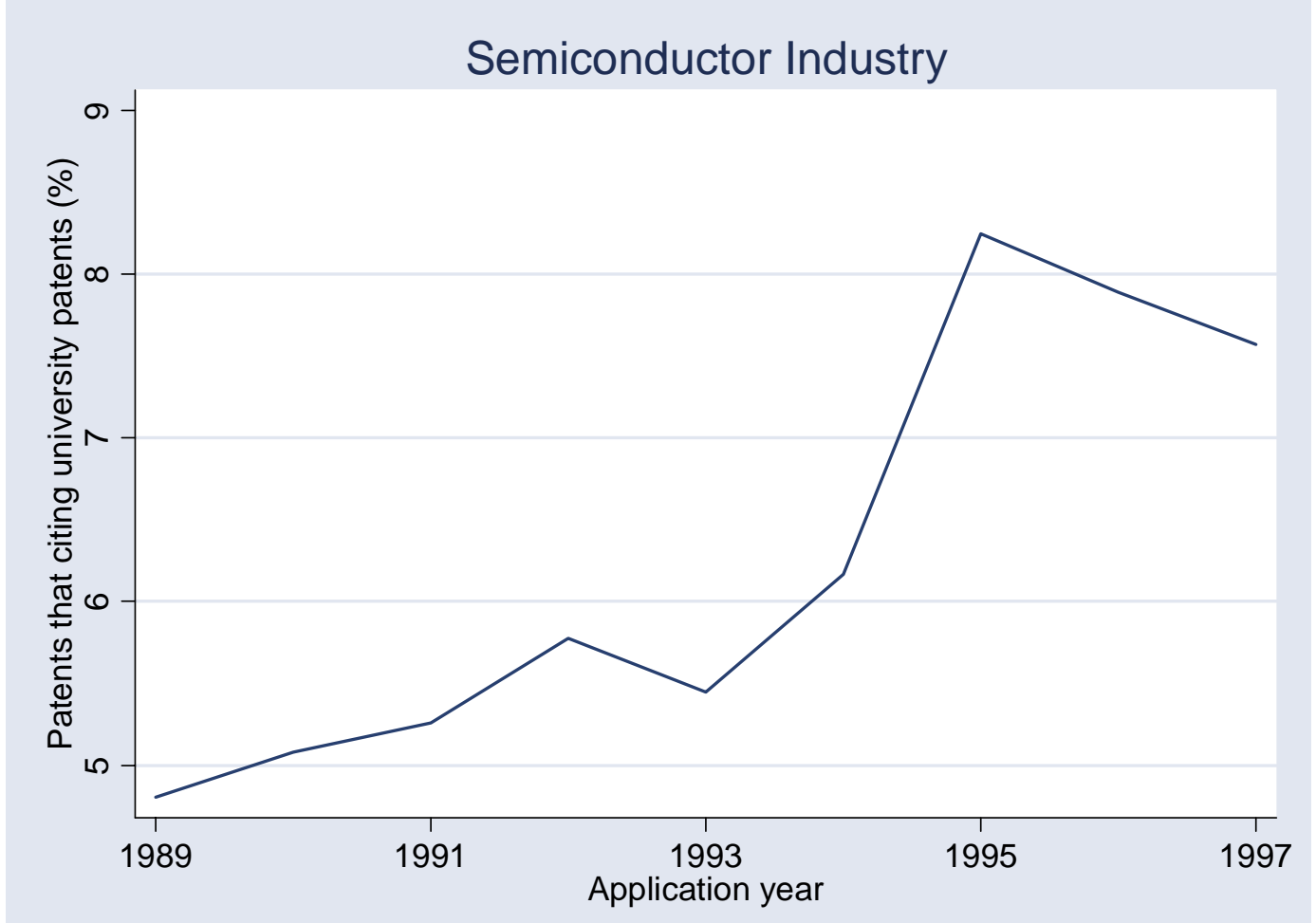

D. Citation Ratio for All Industries

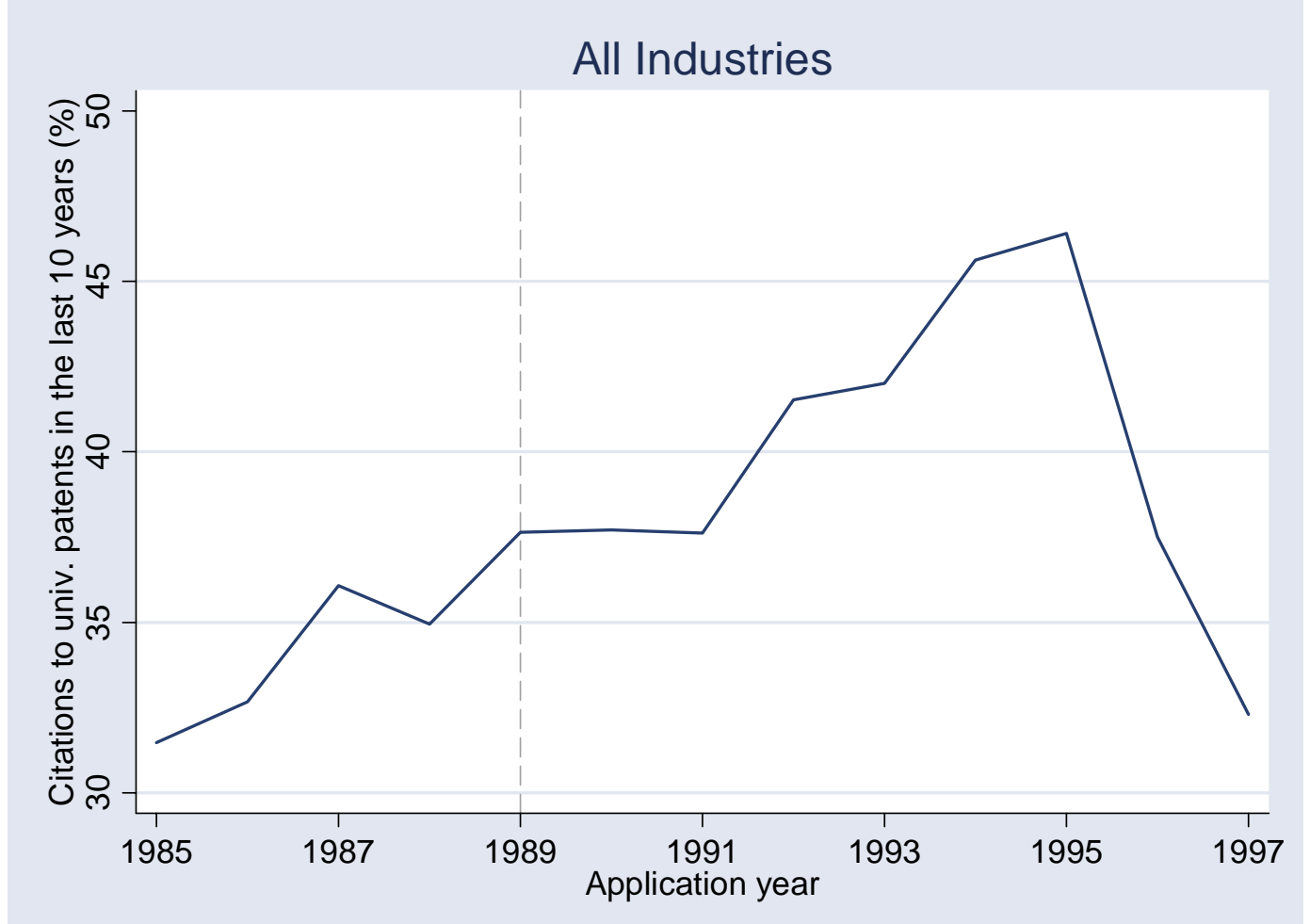


Figure 4 Decomposing the Increase in Patents

(a) that name inventors with university patent experience, (b) that name inventors with advanced degrees, and (c) that cite university patents (1985-1997)

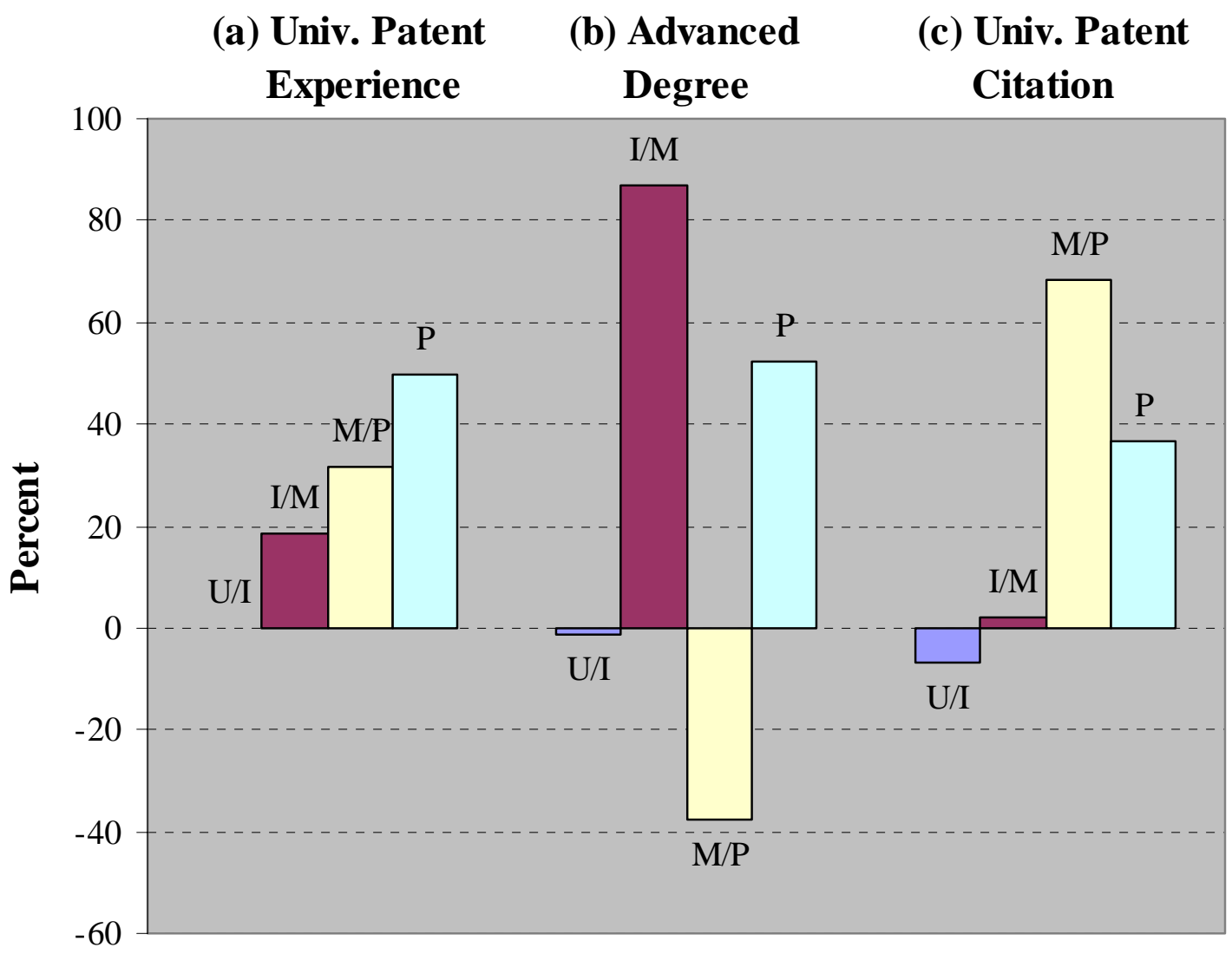


Table 1. Variable Definition and Sample Statistics

\begin{tabular}{|c|c|c|c|}
\hline & \multirow[t]{2}{*}{ Definition } & \multicolumn{2}{|c|}{ Mean (Standard Deviation) } \\
\hline & & Pharmaceutical & Semiconductor \\
\hline UNIV & $\begin{array}{l}\text { Fraction of patents that involve inventors who have university } \\
\text { patenting experience }\end{array}$ & $\begin{array}{c}0.1287 \\
(0.2632)\end{array}$ & $\begin{array}{c}0.0344 \\
(0.1458)\end{array}$ \\
\hline ADVDEG & $\begin{array}{l}\text { Fraction of patents that have inventors on them who have } \\
\text { advanced degrees }\end{array}$ & $\begin{array}{c}0.2988 \\
(0.3277)\end{array}$ & $\begin{array}{c}0.1707 \\
(0.2597)\end{array}$ \\
\hline UCITE & Fraction of patents citing past university-assigned patents & $\begin{array}{c}0.3036 \\
(0.3567)\end{array}$ & $\begin{array}{c}0.0797 \\
(0.1849)\end{array}$ \\
\hline INVENTOR & Number of Inventors & $\begin{array}{c}60.23 \\
(114.5)\end{array}$ & $\begin{array}{l}74.74 \\
(246.8)\end{array}$ \\
\hline EMPLOYEE & Number of Employees & $\begin{array}{c}9,046 \\
(17,249)\end{array}$ & $\begin{array}{c}4,508 \\
(14,876)\end{array}$ \\
\hline $\mathrm{R} \& \mathrm{D} / \mathrm{INV}$ & $\begin{array}{l}\text { Real R\&D expenditures in } 1996 \text { constant dollars over the } \\
\text { number of inventors }\end{array}$ & $\begin{array}{l}31.36 \\
(55.74)\end{array}$ & $\begin{array}{c}22.88 \\
(39.96)\end{array}$ \\
\hline NSIC & Number of secondary SIC’s assigned to a firm & $\begin{array}{l}2.3456 \\
(1.716)\end{array}$ & $\begin{array}{l}1.702 \\
(1.214)\end{array}$ \\
\hline MEXP & Median experience of all inventors in a firm & $\begin{array}{l}5.4796 \\
(3.555)\end{array}$ & $\begin{array}{l}4.550 \\
(3.107)\end{array}$ \\
\hline FIRMAGE & Years elapsed since the founding year of a firm & $\begin{array}{c}29.88 \\
(39.81)\end{array}$ & $\begin{array}{l}19.50 \\
(19.74)\end{array}$ \\
\hline ANYUCITE & $\begin{array}{l}\text { Binary variable for whether a firm has at least one citation to } \\
\text { university patents in year } t\end{array}$ & $\begin{array}{c}0.6897 \\
(0.4629)\end{array}$ & $\begin{array}{c}0.4017 \\
(0.4907)\end{array}$ \\
\hline ANYUSCI & $\begin{array}{l}\text { Binary variable for whether a firm has at least one inventor } \\
\text { with university patenting experience inventor in year } t\end{array}$ & $\begin{array}{c}0.4347 \\
(0.4961)\end{array}$ & $\begin{array}{c}0.1983 \\
(0.3991)\end{array}$ \\
\hline ANYPHD & $\begin{array}{l}\text { Binary variable for whether a firm has at least one inventor } \\
\text { with advanced degree in year } t\end{array}$ & $\begin{array}{c}0.6221 \\
(0.4852)\end{array}$ & $\begin{array}{c}0.5034 \\
(0.5004)\end{array}$ \\
\hline
\end{tabular}


Table 2 Determinants of Firm Use of Inventors with University Patenting Experience

Dependent variable $=$ logit transform of UNIV

\begin{tabular}{l|ccc|ccc}
\hline \hline & \multicolumn{3}{|c|}{ Pharmaceutical } & \multicolumn{3}{c}{ Semiconductor } \\
\hline \multirow{2}{*}{ Log INVENTOR } & 2.5045 & 2.1970 & 2.1777 & 1.4853 & 1.3832 & 1.1757 \\
& 6.91 & 5.00 & 4.89 & 6.74 & 5.98 & 4.69 \\
Log EMPLOYEE & -0.5381 & -0.1871 & -0.1571 & -0.1034 & -0.0088 & 0.1427 \\
& -1.97 & -0.46 & -0.38 & -0.48 & -0.04 & 0.56 \\
Log R\&D/INV & 0.1258 & 0.1550 & 0.1482 & 0.0555 & 0.0641 & 0.0324 \\
& 1.58 & 1.72 & 1.59 & 0.66 & 0.72 & 0.35 \\
Log NSIC & -0.2018 & -0.3801 & -0.3881 & 0.3815 & 0.4732 & 0.7109 \\
& -0.28 & -0.46 & -0.47 & 0.69 & 0.82 & 1.21 \\
Log MEXP & & 3.0469 & 3.0339 & & 0.8233 & 0.8648 \\
& & 5.52 & 5.48 & & 2.31 & 2.43 \\
Log FIRMAGE & -1.4772 & -1.5380 & & -0.2913 & -0.5002 \\
Time trend & -2.03 & -2.05 & & -0.66 & -1.09 \\
& & & 0.0438 & & & 0.2115 \\
\hline Observations & 631 & 505 & 0.30 & & 5.14 \\
$\mathrm{R}^{2}$ & 0.1436 & 0.1940 & 0.1931 & 0.1789 & 0.1873 & 0.1930 \\
\hline
\end{tabular}

Note: All models are estimated with random (firm) effects. 
Table 3 Determinants of Firm Use of Inventors with Advanced Degrees

Dependent variable $=$ logit transform of ADVDEG

\begin{tabular}{l|ccc|ccc}
\hline \hline & \multicolumn{3}{|c|}{ Pharmaceutical } & \multicolumn{3}{c}{ Semiconductor } \\
\hline \multirow{2}{*}{ Log INVENTOR } & 2.7368 & 2.6377 & 2.4313 & 2.4983 & 2.3655 & 2.2626 \\
& 6.62 & 5.31 & 4.86 & 7.02 & 6.31 & 5.56 \\
Log EMPLOYEE & -0.3520 & -0.2187 & 0.0568 & -0.4034 & -0.3539 & -0.2796 \\
& -1.18 & -0.50 & 0.13 & -1.11 & -0.87 & -0.66 \\
Log R\&D/INV & 0.1589 & 0.0939 & 0.0220 & 0.0391 & 0.0055 & -0.0147 \\
& 1.73 & 0.92 & 0.21 & 0.28 & 0.04 & -0.10 \\
Log NSIC & -0.5999 & -1.1006 & -1.2289 & -0.2679 & -0.2634 & -0.1500 \\
& -0.72 & -1.17 & -1.31 & -0.30 & -0.29 & -0.16 \\
Log MEXP & & 0.7651 & 0.6985 & & 0.2133 & 0.2435 \\
& & 1.22 & 1.12 & & 0.39 & 0.44 \\
Log FIRMAGE & -0.5259 & -0.9577 & & -0.2985 & -0.4422 \\
Time trend & -0.67 & -1.20 & & -0.40 & -0.57 \\
& & & 0.4469 & & & 0.1060 \\
\hline Observations & 631 & 505 & 505 & 576 & 556 & 0.69 \\
$\mathrm{R}^{2}$ & 0.1365 & 0.1226 & 0.1280 & 0.1786 & 0.1716 & 0.1739 \\
\hline
\end{tabular}

Note: All models are estimated with random (firm) effects. 
Table 4 Determinants of Citations to University Patents

Dependent variable $=$ logit transform of UCITE

\begin{tabular}{l|ccc|ccc}
\hline \hline & \multicolumn{3}{|c|}{ Pharmaceutical } & \multicolumn{3}{c}{ Semiconductor } \\
\hline \multirow{2}{*}{ Log INVENTOR } & 1.3889 & 1.0221 & 0.9042 & 2.2396 & 2.1427 & 1.7774 \\
& 2.63 & 1.64 & 1.43 & 6.99 & 6.57 & 4.97 \\
Log EMPLOYEE & -0.7168 & -0.5055 & -0.3751 & -0.3376 & -0.3517 & -0.1033 \\
& -1.90 & -0.93 & -0.68 & -1.02 & -0.99 & -0.28 \\
Log R\&D/INV & 0.0656 & 0.0656 & 0.0335 & 0.0247 & 0.0060 & -0.0629 \\
& 0.60 & 0.53 & 0.26 & 0.19 & 0.05 & -0.46 \\
Log NSIC & 0.4175 & 0.3283 & 0.2993 & -0.0938 & -0.4115 & -0.0429 \\
& 0.42 & 0.29 & 0.27 & -0.12 & -0.53 & -0.05 \\
Log MEXP & & 0.3585 & 0.3768 & & 0.4991 & 0.5751 \\
& & 0.45 & 0.47 & & 1.05 & 1.21 \\
Log FIRMAGE & & -0.2034 & -0.3948 & & 0.5248 & 0.0590 \\
Time trend & -0.21 & -0.41 & & 0.79 & 0.09 \\
& & & 0.2078 & & & 0.3196 \\
\hline Observations & 586 & 470 & 470 & & 556 & 538 \\
$\mathrm{R}^{2}$ & 0.0394 & 0.0319 & 0.0376 & 0.2108 & 0.2298 & 0.2348 \\
\hline
\end{tabular}

Note: All models are estimated with random (firm) effects. 
Table 5 Marginal Effects of Regressors in Tables 2-4

\begin{tabular}{|c|c|c|c|c|c|c|}
\hline \multirow[b]{2}{*}{ Dependent variable } & \multicolumn{3}{|c|}{ Pharmaceutical } & \multicolumn{3}{|c|}{ Semiconductor } \\
\hline & UNIV & ADVDEG & UCITE & UNIV & ADVDEG & UCITE \\
\hline Log INVENTOR & 0.2464 & 0.5526 & 0.2161 & 0.0459 & 0.3349 & 0.1572 \\
\hline Log EMPLOYEE & -0.0210 & -0.0458 & -0.1069 & -0.0003 & -0.0501 & -0.0258 \\
\hline Log R\&D/INV & 0.0174 & 0.0197 & 0.0139 & 0.0021 & 0.0008 & 0.0004 \\
\hline Log NSIC & -0.0426 & -0.2306 & 0.0694 & 0.0157 & -0.0373 & -0.0302 \\
\hline Log MEXP & 0.3417 & 0.1603 & 0.0758 & 0.0273 & 0.0302 & 0.0366 \\
\hline Log FIRMAGE & -0.1656 & -0.1102 & -0.0430 & -0.0097 & -0.0423 & 0.0385 \\
\hline
\end{tabular}

Note: All the numbers in this table are based on the coefficients reported in the second column of each panel in tables 2-4. The marginal effect is calculated by $y_{m}\left(1-y_{m}\right) \beta$ where $y_{m}$ is the sample mean of the dependent variable and $\beta$ is the estimated coefficient. 
Table 6 Effect of University Affiliation on Citations to University Patents

\begin{tabular}{|c|c|c|c|c|c|c|c|c|}
\hline \multirow[b]{2}{*}{$\begin{array}{r}\text { Dependent variable } \\
\text { Model }\end{array}$} & \multicolumn{4}{|c|}{ Pharmaceutical } & \multicolumn{4}{|c|}{ Semiconductor } \\
\hline & $\begin{array}{r}\text { ANY } \\
\text { P }\end{array}$ & $\begin{array}{l}\text { CITE } \\
\text { jit }\end{array}$ & $\begin{array}{r}\mathrm{U} \\
\text { Reg }\end{array}$ & $\begin{array}{l}\Gamma E \\
\text { sion }\end{array}$ & $\begin{array}{l}\mathrm{ANY} \\
\mathrm{P}\end{array}$ & $\begin{array}{l}\text { CITE } \\
\text { it }\end{array}$ & $\begin{array}{r}\mathrm{U} \\
\mathrm{Reg}\end{array}$ & $\begin{array}{l}\Gamma E \\
\text { sion }\end{array}$ \\
\hline ANYUSCI & $\begin{array}{c}0.8538 \\
3.98\end{array}$ & & $\begin{array}{c}4.8418 \\
3.93\end{array}$ & & $\begin{array}{c}0.7960 \\
3.45\end{array}$ & & $\begin{array}{c}2.4361 \\
2.60\end{array}$ & \\
\hline ANYPHD & & $\begin{array}{c}0.2933 \\
1.47\end{array}$ & & $\begin{array}{c}2.5764 \\
1.86\end{array}$ & & $\begin{array}{c}0.2400 \\
1.39\end{array}$ & & $\begin{array}{c}0.9853 \\
1.32\end{array}$ \\
\hline Log INVENTOR & $\begin{array}{c}0.4394 \\
4.32\end{array}$ & $\begin{array}{c}0.4893 \\
4.48\end{array}$ & $\begin{array}{c}0.1668 \\
0.26\end{array}$ & $\begin{array}{c}0.5024 \\
0.74\end{array}$ & $\begin{array}{c}0.6130 \\
7.45\end{array}$ & $\begin{array}{c}0.6490 \\
7.28\end{array}$ & $\begin{array}{c}1.8428 \\
5.35\end{array}$ & $\begin{array}{c}1.9605 \\
5.54\end{array}$ \\
\hline Log EMPLOYEE & $\begin{array}{c}-0.0417 \\
-0.58\end{array}$ & $\begin{array}{c}-0.0335 \\
-0.45\end{array}$ & $\begin{array}{c}-0.4846 \\
-0.91\end{array}$ & $\begin{array}{c}-0.4879 \\
-0.90\end{array}$ & $\begin{array}{c}-0.1441 \\
-2.03\end{array}$ & $\begin{array}{c}-0.1392 \\
-1.89\end{array}$ & $\begin{array}{l}-0.3423 \\
-0.96\end{array}$ & $\begin{array}{c}-0.3518 \\
-0.98\end{array}$ \\
\hline Log R\&D/INV & $\begin{array}{c}0.0293 \\
1.48\end{array}$ & $\begin{array}{c}0.0326 \\
1.65\end{array}$ & $\begin{array}{c}0.0289 \\
0.24\end{array}$ & $\begin{array}{c}0.0720 \\
0.59\end{array}$ & $\begin{array}{c}-0.0223 \\
-0.78\end{array}$ & $\begin{array}{c}-0.0164 \\
-0.57\end{array}$ & $\begin{array}{c}-0.0058 \\
-0.04\end{array}$ & $\begin{array}{c}-0.0005 \\
0.00\end{array}$ \\
\hline Log NSIC & $\begin{array}{c}0.0434 \\
0.24\end{array}$ & $\begin{array}{c}0.0532 \\
0.29\end{array}$ & $\begin{array}{c}0.2847 \\
0.26\end{array}$ & $\begin{array}{c}0.5269 \\
0.47\end{array}$ & $\begin{array}{c}-0.0645 \\
-0.37\end{array}$ & $\begin{array}{c}-0.0219 \\
-0.12\end{array}$ & $\begin{array}{l}-0.5106 \\
-0.66\end{array}$ & $\begin{array}{c}-0.3965 \\
-0.51\end{array}$ \\
\hline Log MEXP & $\begin{array}{c}0.0371 \\
0.33\end{array}$ & $\begin{array}{c}0.1330 \\
1.22\end{array}$ & $\begin{array}{c}-0.1107 \\
-0.14\end{array}$ & $\begin{array}{c}0.2697 \\
0.34\end{array}$ & $\begin{array}{c}0.0762 \\
0.65\end{array}$ & $\begin{array}{c}0.1061 \\
0.88\end{array}$ & $\begin{array}{c}0.4176 \\
0.88\end{array}$ & $\begin{array}{c}0.4851 \\
1.02\end{array}$ \\
\hline Log FIRMAGE & $\begin{array}{c}0.0103 \\
0.08\end{array}$ & $\begin{array}{c}-0.0239 \\
-0.19\end{array}$ & $\begin{array}{c}0.0510 \\
0.05\end{array}$ & $\begin{array}{c}-0.1438 \\
-0.15\end{array}$ & $\begin{array}{c}0.0600 \\
0.49\end{array}$ & $\begin{array}{c}0.0650 \\
0.51\end{array}$ & $\begin{array}{c}0.4983 \\
0.75\end{array}$ & $\begin{array}{c}0.5506 \\
0.82\end{array}$ \\
\hline $\begin{array}{l}\text { Observations } \\
\text { Log Likelihood or } \mathrm{R}^{2}\end{array}$ & $\begin{array}{c}505 \\
-216.54\end{array}$ & $\begin{array}{c}505 \\
-223.83\end{array}$ & $\begin{array}{c}470 \\
0.0919\end{array}$ & $\begin{array}{c}470 \\
0.0469\end{array}$ & $\begin{array}{c}556 \\
-259.50\end{array}$ & $\begin{array}{c}556 \\
-264.51\end{array}$ & $\begin{array}{c}538 \\
0.2509\end{array}$ & $\begin{array}{c}538 \\
0.2341\end{array}$ \\
\hline
\end{tabular}

Note: All models are estimated with random (firm) effects. 